\title{
Pigment production by cold-adapted bacteria and fungi: colorful tale of cryosphere with wide range applications
}

\author{
Wasim Sajjad ${ }^{1} \cdot{\text { Ghufranud } \mathrm{Din}^{2} \cdot \text { Muhammad Rafiq }^{3} \cdot \text { Awais Iqbal }^{4} \cdot \text { Suliman Khan }}^{5} \cdot$ Sahib Zada $^{6} \cdot$ Barkat Ali $^{1}$. \\ Shichang Kang ${ }^{1,7}$
}

Received: 27 March 2020 / Accepted: 18 May 2020 / Published online: 1 June 2020

(c) Springer Japan KK, part of Springer Nature 2020

\begin{abstract}
Pigments are an essential part of everyday life on Earth with rapidly growing industrial and biomedical applications. Synthetic pigments account for a major portion of these pigments that in turn have deleterious effects on public health and environment. Such drawbacks of synthetic pigments have shifted the trend to use natural pigments that are considered as the best alternative to synthetic pigments due to their significant properties. Natural pigments from microorganisms are of great interest due to their broader applications in the pharmaceutical, food, and textile industry with increasing demand among the consumers opting for natural pigments. To fulfill the market demand of natural pigments new sources should be explored. Cold-adapted bacteria and fungi in the cryosphere produce a variety of pigments as a protective strategy against ecological stresses such as low temperature, oxidative stresses, and ultraviolet radiation making them a potential source for natural pigment production. This review highlights the protective strategies and pigment production by cold-adapted bacteria and fungi, their industrial and biomedical applications, condition optimization for maximum pigment extraction as well as the challenges facing in the exploitation of cryospheric microorganisms for pigment extraction that hopefully will provide valuable information, direction, and progress in forthcoming studies.
\end{abstract}

Keywords Cryosphere $\cdot$ Microbial pigments $\cdot$ Cold-adapted microbes $\cdot$ Carotenoid $\cdot$ Melanin

Communicated by L. Huang.

Shichang Kang

shichang.kang@1zb.ac.cn

1 State Key Laboratory of Cryospheric Science, Northwest Institute of Eco-Environment and Resources, Chinese Academy of Sciences, Lanzhou 730000, China

2 Department of Microbiology, Quaid-I-Azam University, Islamabad 45320, Pakistan

3 Department of Microbiology, Faculty of Life Sciences and Informatics, Balochistan University of IT, Engineering and Management Sciences, Quetta, Pakistan

4 School of Life Sciences, State Key Laboratory of Grassland Agro-Ecosystems, Lanzhou University, Lanzhou, People's Republic of China

5 The Department of Cerebrovascular Diseases, The Second Affiliated Hospital of Zhengzhou University, Zhengzhou, China

6 Department of Biology, College of Science, Shantou University, Shantou, China

7 CAS Center for Excellence in Tibetan Plateau Earth Sciences, Beijing, China

\section{Introduction}

Think for a while, without hemoglobin how oxygen molecules can be carried within a living body or without chlorophyll and other necessary pigments; how plants and other primary producers could prepare their food? Surely impossible. It shows life on this planet depends on pigments. Pigments have been used as coloring agents since the prehistoric era. Sir William Henry Perkin prepared the earliest synthetic dye in 1856 named mauvine. The development of mauvine initiated a historical revolution of synthetic dyes (Walford 1980). Initially, the synthetic dyes gained much attraction due to several characteristics such as easy to develop, economical, no undesirable flavors, excellent coloring properties, and needed in a small amount to use. However, most of the synthetic dyes used had never been tested for their toxic nature for health and adverse effects on the environment (Downham and Collins 2000). In general, synthetic dyes are made up of chemical compounds composed of lead, mercury, copper, chromium, sodium chloride, benzene, and toluene that are harmful to human health. Several 
synthetic colorants previously permitted by the Food and Drug Administration (FDA) to use in medicines, food, and cosmetics development were later found carcinogenic (Rao et al. 2017). Some of these synthetically-derived colorants banned by the FDA include ethyl acrylate, benzophenone, eugenyl methyl ether (methyl eugenol), pulegone, myrcene, and pyridine. Similarly, several synthetic dyes like cochineal red, tartrazine, and sunset yellow initiate allergies directly or indirectly by combining with other colorants. The Center for Science in the Public Interest in Washington appealed to the FDA in 2008 to disallow synthetic food colorants since of their association with behavioral harms among children (Potera 2010). Most synthetic dyes previously used for various purposes are now quit due to apparent hazards such as carbon black (extensively used as printing ink pigment) a potential carcinogen and benzidine a causative agent of bowel cancer (Rao et al. 2017). Moreover, the unethical release of untreated dye effluents from industries persists for a longer time due to higher stability. Due to the aforementioned drawbacks of synthetic dyes, global demand for natural pigments has been increased (Manikprabhu and Lingappa 2013). Being aware of the adverse effects causing by synthetic dyes, now consumers prefer natural ingredients in their food instead of artificial (Downham and Collins 2000). This has raised the demand for naturally derived pigments.

The use of natural colorants is believed to be relatively safe, since their nature is biodegradable, harmless, and noncarcinogenic (Cristea and Vilarem 2006). Globally, the trend is shifting towards the consumption of biodegradable and environmentally friendly commodities; therefore, the demand for natural colorants is increasing in pharmaceutical, dyestuff, foodstuff, and cosmetics. Waste materials that are environmental pollutants have been used for microbial pigment production, which made this process more sustainable (Joshi et al. 2003; Kamla et al. 2012). Natural biocolorants that are an alternative to synthetic pigments could be obtained from plants and microorganisms. Natural pigments obtained from microbes are more ideal over plants due to the solubility, and stability of pigments and the easy availability of microbes for culturing (Rao et al. 2017). The fast growth of microorganisms in inexpensive medium, easy downstream processing, and their constant cultivation independent of the seasonal variations are advantages of microbes over plants as a source of pigment production (Manikprabhu and Lingappa 2013). Moreover, the use of plants on a large scale can cause damage to the precious species; therefore, the practice is not sustainable (Downham and Collins 2000). Additionally, the yearly growth rate of natural dyes has been projected 5-10\% compared to synthetically derived dyes having a lower growth rate of 3-5\% (Parmar and Phutela 2015). Pigments produced by microorganisms are not merely colors but consist of diverse chemical components having multidimensional biological activities (Kim
2013). Among microorganisms, bacteria, fungi, and microalgae offer an alternate source for natural pigments (Joshi et al. 2003; Choi et al. 2015; Rao et al. 2017; Pandey et al. 2018; Ramesh et al. 2019).

Earth's cryosphere has been thought too hostile to harbor life for a long time. However, being extreme ecological conditions, diverse microbial communities exist in the glacial ecosystem (Anesio et al. 2017; Hassan et al. 2018; Rafiq et al. 2019) that maintain active biochemical routes (Anesio and Laybourn-Parry 2012). The microbial communities inhabiting the cryosphere are constantly exposed to several stress conditions such as extremely low temperatures, oligotrophic conditions, freeze-thaw cycles, ultraviolet (UV) radiations, and higher salinity. To cope with these hostile conditions, microorganisms adapt several protective strategies including morphological alteration and production of various metabolites. Most of these metabolites have important biotechnological and industrial applications (Cavicchioli et al. 2011). Among these metabolites, pigments are charismatic traits of these cold-adapted microorganisms that are studied to exploit for several industrial applications. Pigments production mostly occurs within cytoplasm as a responsive agent to hostile ecological conditions presenting several ecological functions (Pagano and Dhar 2015). Physiochemically extreme environments such as the cryosphere provide a suitable setup to microorganisms for pigment production with unique qualities and applications. In this review, pigments produced by cold-adapted bacteria and fungi in the cryosphere and their potential applications in various industries are discussed. Moreover, condition optimization for maximum pigment yield as well as the challenges facing in the exploitation of cryospheric microorganisms for pigment extraction are discussed.

\section{Challenges in cryosphere and microbial adaptation mechanisms}

Cryosphere has been dominated and colonized by diverse microorganisms collectively termed as psychrophiles or cold-adapted microorganisms. Life spin and activity of several microorganisms significantly reduce below $0{ }^{\circ} \mathrm{C}$ (Tribelli and López 2018). However, psychrophilic and psychrotrophic microorganisms withstand the hostile environments of cryosphere and adapt to grow below $5{ }^{\circ} \mathrm{C}$ (close to zero). Low temperature reduces thermal energy with increased viscosity of solvents and solubility of gasses such as oxygen molecules and reactive oxygen species (ROS), reduced solubility of nutrients and solutes, decreased diffusion as well as amplify desiccation, osmotic stress, and ice development. Moreover, life in the cryosphere experience several environmental stresses including high salinity, low availability of nutrients, oxidative stress, low water activity, 
and freeze-thaw cycles. High-pressure stress is subjected to microbial population inhabiting in deep-sea and subglacial habitats. Additionally, psychrophilic microbes are exposed to extremes of light, exposure to UV radiations, and bright light at high elevation and low light in frosted lakes, permafrost, and deeper ice sheets. To cope with these life-endanger challenges microorganisms adapt and develop certain sophisticated strategies (Margesin and Collins 2019; Collins and Margesin 2019). Previously, several microbiological, physiological, biochemical, biophysical, and molecular-based approaches have been adapted to identify biogeographical distribution, physiological adaptation, diversity, and ecological role of psychrophiles. However, recent advances in 'omics' technologies such as genomics, metagenomics, transcriptomics, and proteomics have uncovered novel adaptation mechanisms and environmental functions of microorganisms in the cryosphere (Singh et al. 2014; Barauna et al. 2017; Tribelli and Lopez 2018). Several mechanisms adapted by microorganisms to cope with the hostile environment of cryosphere are shown in Fig. 1.

At low temperatures, psychrophiles alter their cellular envelope and components to provide shape, support, and protection to cells; regulate nutrient uptake and solute transport; and participate in cell division, adhesion, signaling, and sensing. This alteration is against the low temperature that reduces membrane permeability, fluidity, diffusion rates, and cause cell rupturing due to freeze-thaw cycles and ice formation. Psychrophiles modify the composition of fatty acid in lipid bilayer present in the cell membranes and become homeoviscous (D'Amico et al. 2001; Siddiqui et al. 2013). Contents of unsaturated fatty acids, short-chain, methyl branched, and/or cis-isomeric can manage the low temperature stress (Hassan et al. 2020) by lowering the liquid phase phospholipid bilayer to gel phase and sustain their function. For this adaptation, upregulation and overrepresentation of genes occur that encode proteins involved in membrane biogenesis and biosynthesis and desaturation of fatty acids (desaturases that also guard against ROS), biosynthesis of branched-chain fatty acids (KAS-II, KASIII) and cis-isomerization (fatty acid cis/trans isomerases) (Medigue et al. 2005; De Maayer et al. 2014; He et al. 2015; Goordial et al. 2016). Furthermore, psychrophiles upregulate the membrane transport proteins that could counter the reduced diffusion rates at lower temperatures (Bakermans et al. 2007; De Maayer et al. 2014). Long-chain polyunsaturated fatty acids (LC-PUFAs) (Yoshida et al. 2016) also shield the membrane by generating hydrophobic edges between the lipid bilayers, which prevents the entrance of ROS augmented at low temperatures. Polyunsaturated fatty acids (PUFAs) can act as chaperons for proteins in the membrane, which could be functional in cell division and the efflux process (Okuyama et al. 2008; Yoshida et al. 2016). Turk et al. (2011) reported higher membrane fluidity in psychrotolerant yeast Rhodosporidium diobovatum suggesting that LC-PUFAs maintain the integrity and functionality of the plasma membrane. Similarly, psychrophiles upregulate certain genes encoding peptidoglycan biosynthesis and thicken their peptidoglycan (Mykytczuk et al. 2013), which can protect psychrophiles against freeze-thaw cycle, ice formation, and osmotic pressure. The lipopolysaccharides

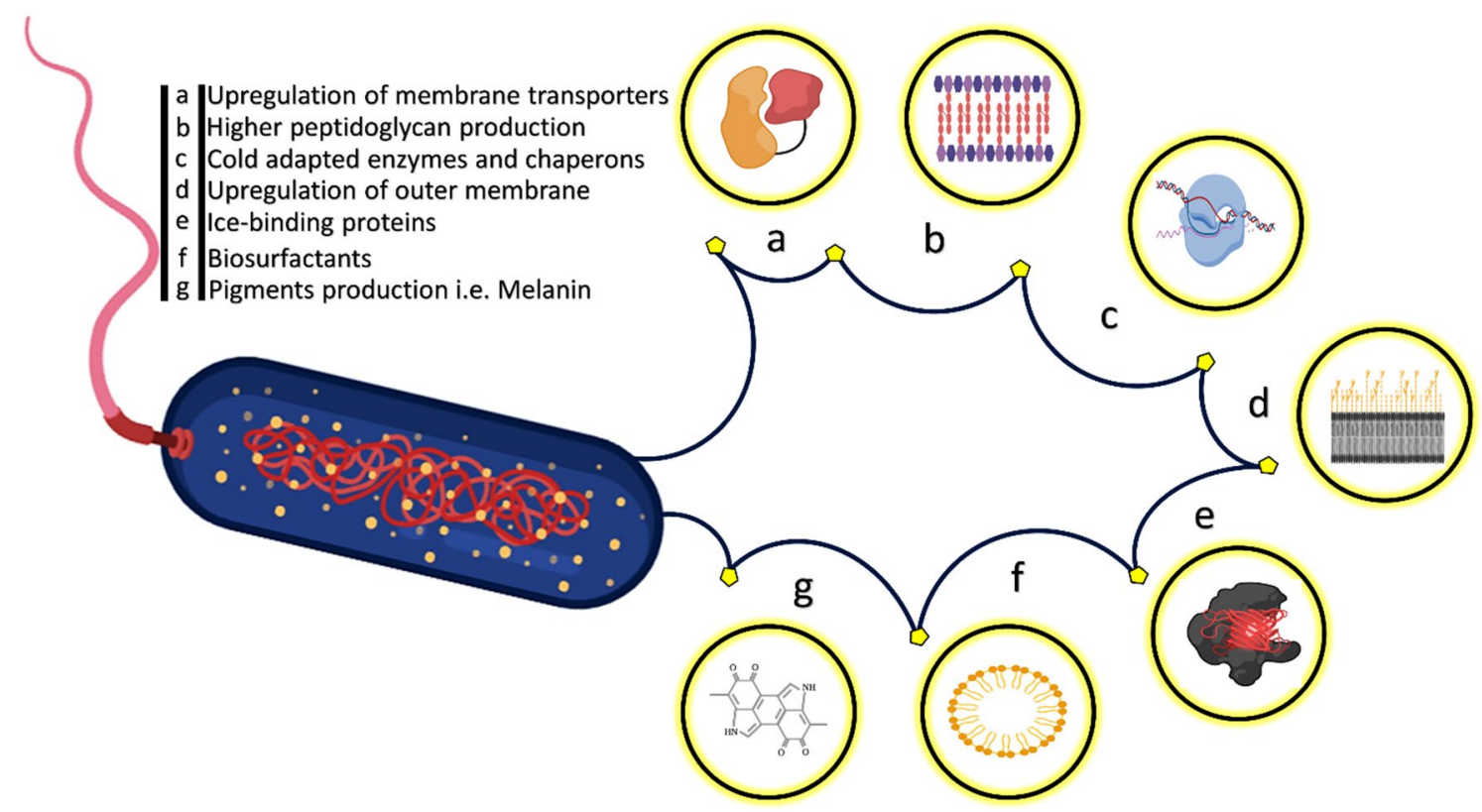

Fig. 1 Common strategies adapted by psychrophiles to cope with low temperatures and other stresses in the cryosphere 
(LPS) layer in psychrophiles are shortened in length lacking the O-chain component (Corsaro et al. 2017) that may enhance the flexibility and stability of the outer membrane. Genes encoding for the synthesis of outer membrane components, proteins, and LPS (largely glycosyl transferases) was reported upregulated at lower temperatures (Frank et al. 2011; De Maayer et al. 2014). Benforte et al. (2018) reported that how a mutation in the glycosyl transferase gene (wapH) reduced the growth pattern of the Antarctic bacterium at lower temperatures. Several psychrophiles have higher genome contents encoding for compatible solute biosynthesis and uptake genes that could accumulate compatible solutes in molar concentrations, with glycine betaine, glycerol, mannitol, trehalose, sarcosine, sucrose, and sorbitol (Mykytczuk et al. 2013; Ghobakhlou et al. 2015; Goordial et al. 2016) that could restore osmotic balance and cell shrinkage. Fungi synthesize certain compatible solutes to cope with osmotic pressure and dehydration in the cryosphere such as mannitol that acts as a cryoprotective (Feofilova et al. 1994). Psychrophiles produce antifreeze proteins (AFPs) that bind to ice and inhibit ice development and recrystallization. AFPs preserve the liquid present in the close vicinity of cells (Raymond et al. 2008). These AFPs also stabilize cell membranes, structural integrity, and position the cell for increase contact towards nutrients and oxygen in the phototrophic region (Lorv et al. 2014; Bar Dolev et al. 2016; Voets 2017). Another protein called ice-nucleating proteins (INPs) reported in psychrophiles prevent cryoinjury of the cell by inhibiting intracellular ice formation (Lorv et al. 2014). Cold-adapted bacteria produce a high concentration of extracellular polymeric substances (EPS) at low temperatures (Mykytczuk et al. 2013; Caruso et al. 2018) which could form a protective shell around the cells. EPS produced by psychrophilic microorganisms could act as osmoprotective, ROS scavenging, and cryoprotective (Ewert and Deming 2013; Deming and Young 2017). Along with low temperature adaptation, biosurfactant (glycolipid) reported from Antarctic yeast showed ice recrystallization inhibition activity (Kitamoto et al. 2001), also such biosurfactants act as osmolytes (Perfumo et al. 2018). The main adverse effect of low temperature is on the cellular reaction rate of mesophilic microorganisms that either halts their cellular growth or cause death due to cellular lysis. However, psychrophiles produce enzymes that perform high catalytic activities in cold environments, therefore, optimally grow at low temperatures (Santiago et al. 2016; Collins and Gerday 2017). Psychrophiles overcome the obstacle of reduced enzyme activity by developing a changed system for the transportation of nutrients and waste products; altered cellular processes of transcription and translation, and cell division cycle, and decrease the fluidity of membrane to grow in low temperature (D'Amico et al. 2006). Cold-adapted organisms produce chaperones that efficiently fold proteins and
DNA/RNA and stabilize the secondary structures of these molecules at low temperatures. Psychrophiles upregulate the production of protein and DNA/RNA chaperones as cold acclimation proteins (Lim et al. 2000). Recently by adapting omics approaches have discovered various traits that are common to psychrophiles (Tribelli and Lopez 2018). One such trait is the metabolic adjustment at sub-zero temperature that takes place in psychrophiles such as the downregulation of primary metabolic pathways and replacement with alternate secondary pathways and accumulations and digestion of spare compounds. Cellular metabolic routes like glycolysis, tricarboxylic acid cycle, electron transport chain, and pentose phosphate pathway get downregulated in coldadapted microorganisms (Medigue et al. 2005; Piette et al. 2011; Tribelli et al. 2015). Such metabolic reprogramming could protect oxidative stress and conserve energy for longterm survival. Another important protective mechanism adapted by psychrophilic microorganisms is the production of pigments. Psychrophiles reported from ice-cores and glaciers were capable to produce pigments (Shen et al. 2018). Melanin pigment reported in fungi protects stresses such as ionizing radiation, desiccation, oxidizing agents, and UV radiations (Butler and Day 1998; Gorbushina 2003). Antarctic fungal species having melanin were reported, which were resistant to UV radiation (Hughes et al. 2003). Several fungal strains produce mycosporines that absorb UV radiations (Sommaruga et al. 2004). Similarly, psychrophilic bacteria produce carotenoid as a protection mechanism in cryospheric environments (Vila et al. 2019). Moreover, these pigments also play role in photoprotection (in combination with other molecules like mycosporine and scytonemin like amino acids, and act as a protector against intense light range and UV irradiation), act as cryoprotectants, antioxidants, and antimicrobials (Dieser et al. 2010; Pandey et al. 2018).

\section{Role of pigments in cold-adapted microbes}

In general, pigments are secondary metabolites produced by microbes and are not necessarily produced by all kinds of microorganisms. Cold-adapted bacteria and fungi inhabiting cryospheric environments produce a diverse range of pigments (Table 1). The pigment production by microbes in extremely low temperature environments is a mechanism to survive ecological stresses. They consume pigment molecules as an energy source (Madigan et al. 2012), for the process of photosynthesis (Siefirmann-Harms 1987), as a confrontation tool against stress (Martin-Cerezo et al. 2015), oxidants, extreme temperature and desiccation (Wada et al. 2013), and for safety against UV irradiation (Becker-Hapak et al. 1997). Moreover, pigments also act as an antimicrobial agent against other bacteria (Suresh et al. 2015) and sometimes act as a shield to protect the cell against natural 


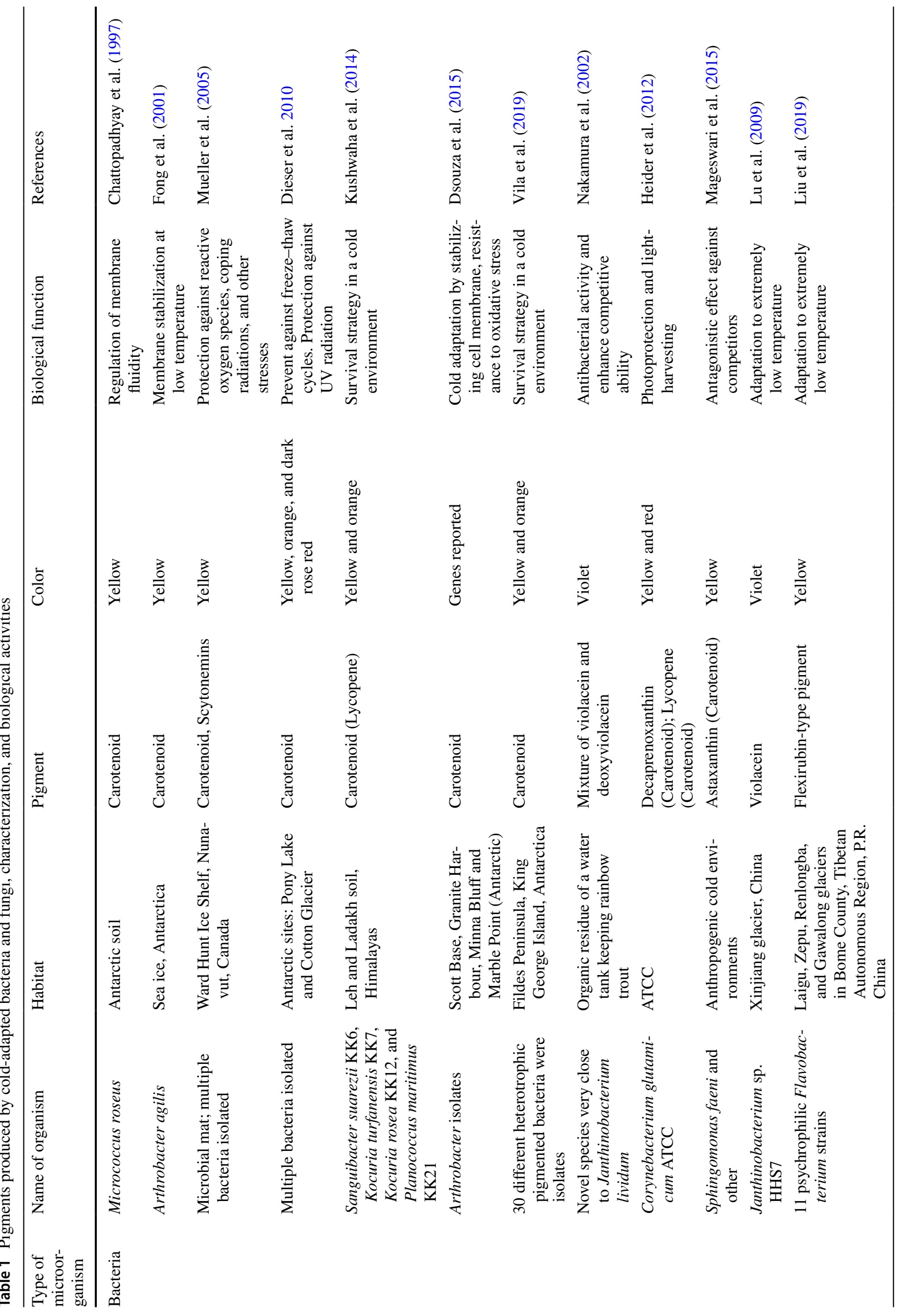




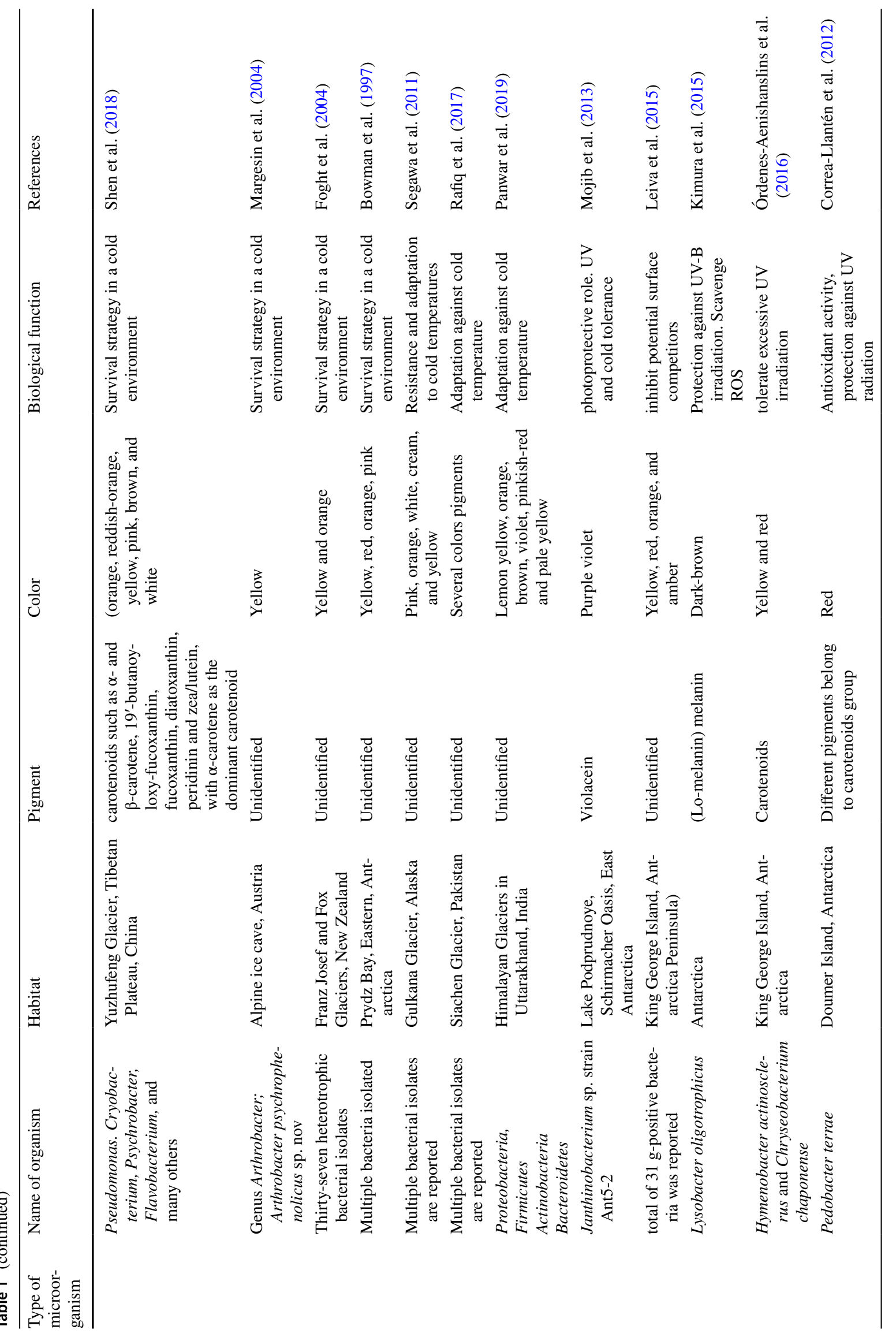




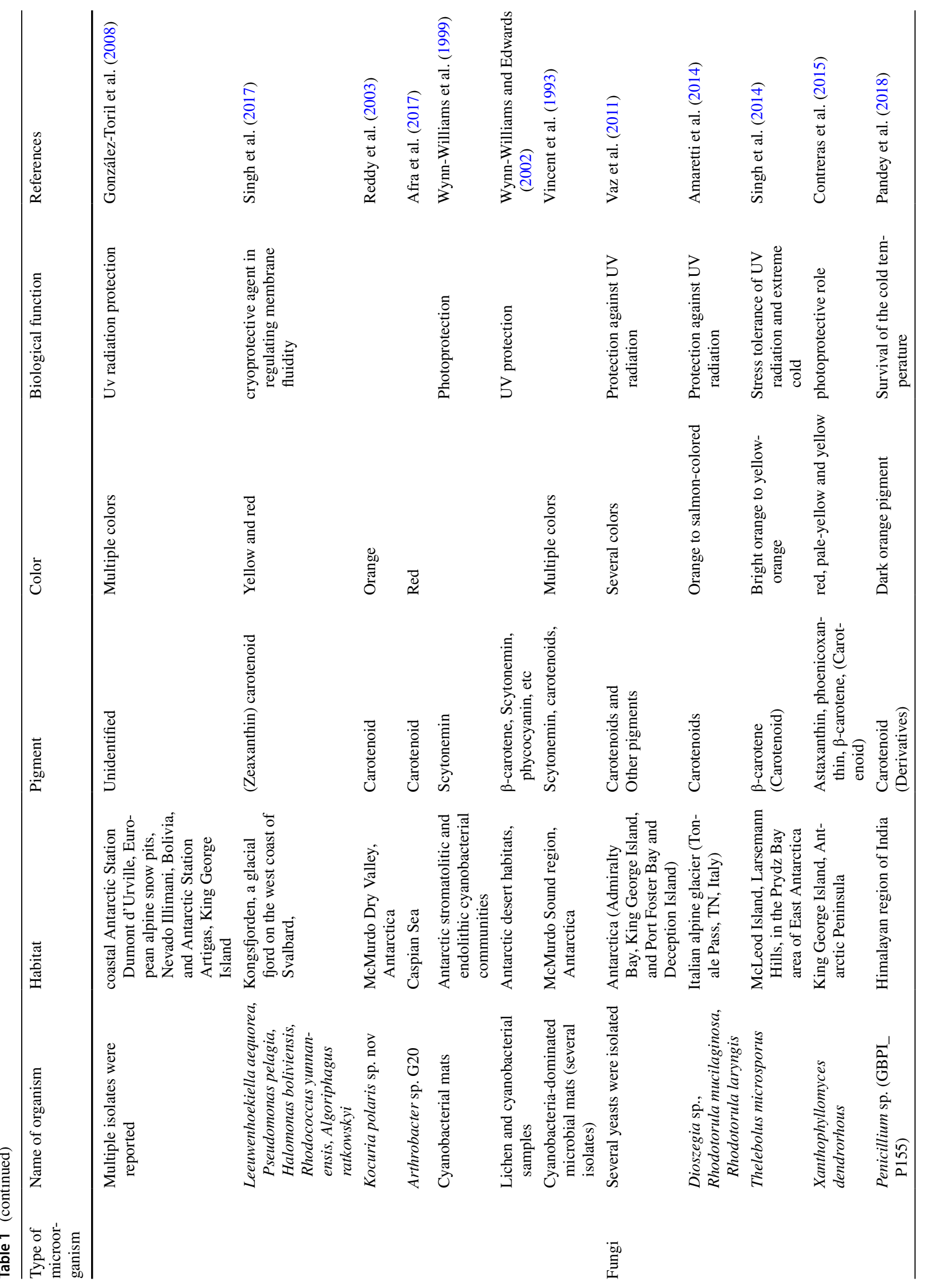




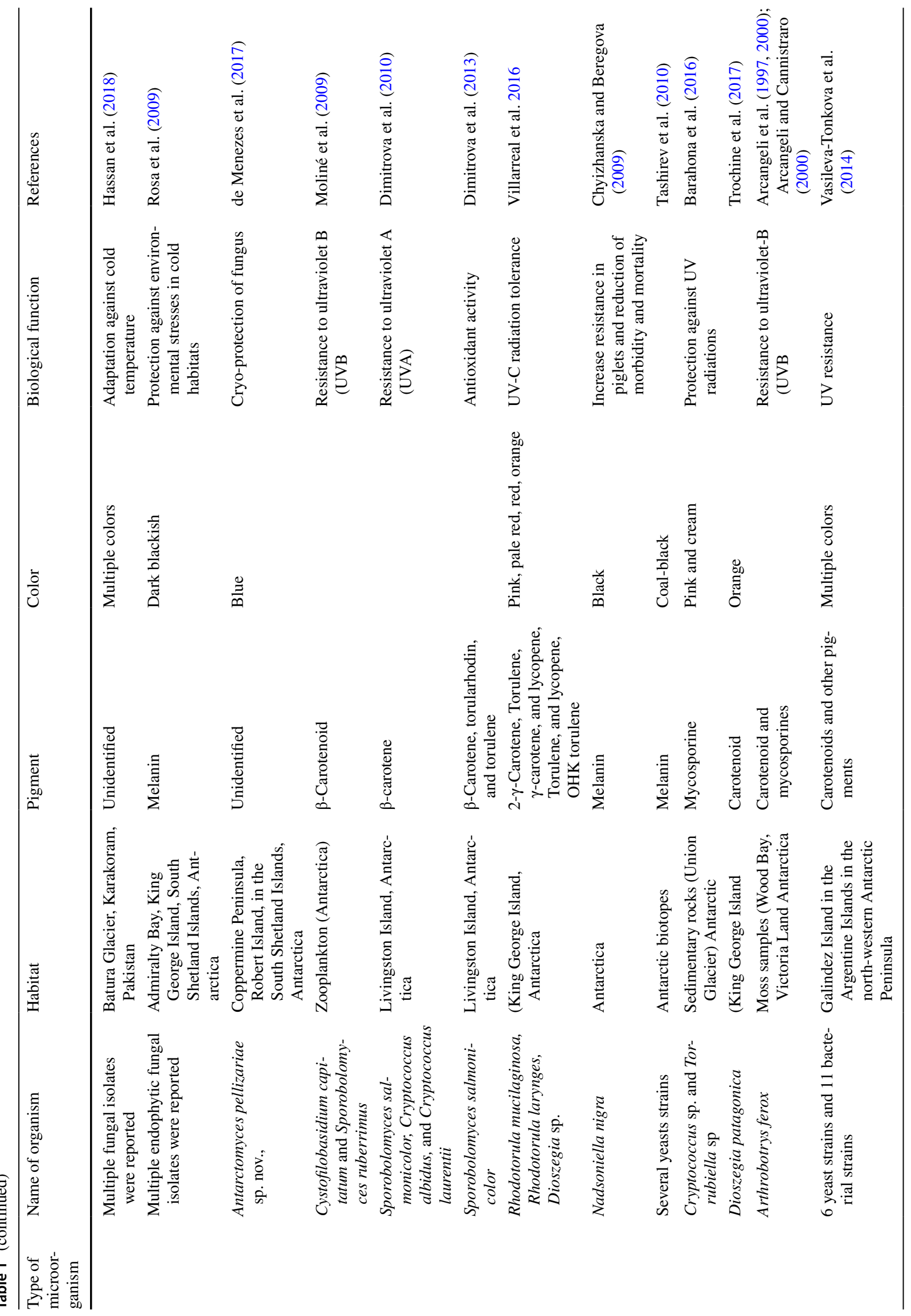


antimicrobial compounds secreted by other bacteria (van Duin et al. 2002). High diversity of pigment molecules are reported from microorganisms inhabiting in glaciers (Foght et al. 2004), ice cores (Zhang et al. 2008), and marine surface waters (Agogué et al. 2005) which shows that this pigment production is essential to cope with the environmental stresses in the cryosphere. Such as carotenoid modulate the cellular membrane fluidity of bacteria as an adaptive strategy in the cryosphere. Polar microbial communities are concurrently exposed to UV radiations, highly active photosynthetic radiations, and extremely low temperatures which make them more prone to photo-damage (Roos and Vincent 1998). Therefore, the adaptation of protective strategies by microorganisms is crucial in these habitats. In such harsh environmental conditions, pigment production efficiently decreases photo-damage and could provide resources for osmoregulation, thus provide tolerance against salinity, desiccation, and freeze-thaw cycles and prevent serious damages such as inhibition of metabolic processes and cellular repair mechanisms (Mueller et al. 2005). Depend upon the composition and concentration of pigments, the production could visibly provide coloration to snow such as green due to chlorophylls, various yellow shades due to xantophylls, and orange to red due to carotenoids (Anesio et al. 2017).

\section{Pigments produced by cold-adapted bacteria and fungi}

\section{Carotenoid}

Carotenoids are the main natural pigments widely produced by plants and microorganisms and initially were reported by H.W.F Wackenroder (Wackenroder 1831). Currently, carotenoids signify the largest and highly diverse known group of natural pigments, and 1183 carotenoid structures are compiled from 702 source organisms by Carotenoid Database Japan (https://carotenoiddb.jp). Carotenoid is the family of tetraterpenoids consists of an extensively conjugated polyene, which absorbs blue light and appears from yellow to red in shade (Fraser and Bramley 2004). The structure of carotenoids acquires the form of a polyene hydrocarbon chain that is occasionally terminated by rings with or without extra oxygen atoms. Carotenoids are classified into carotenes, which are hydrocarbons (torulene, lycopene, and $\alpha$ - to $\varepsilon$-carotenes) or xanthophylls that possess keto, hydroxyl, and/or carboxyl groups (lutein, zeaxanthin, torularhodin, and astaxanthin,) (Table 2). Naturally, carotenoids are extensively produced by plants and microorganisms as a photo-protectants. The color of carotenoids ranging from yellow to deep red depending on the structure (Alija et al. 2005; Rao and Rao 2007). The maximum absorption capacity of carotenoids is ranged from 440 to $520 \mathrm{~nm}$, having a stronger molar absorption coefficient (ca. $10^{5} \mathrm{~L} \mathrm{~mol}^{-1} \mathrm{~cm}^{-1}$ ) (Marizcurrena et al. 2019). Cryospheric habitats especially glacial environment provide suitable conditions for pigment production by microorganisms. These pigments also protect the bacterial cells either screening or absorbing UV radiation (Dieser et al. 2010). Carotenoids safeguard microbial cells from photo-oxidative injury and other environmental stresses at low temperatures either by inhibiting the ROS generation through thermal degeneracy of the extra energy or satisfying the excited states of singlet oxygen and chlorophyll (Tian and Hua 2010). Moreover, these pigments play a crucial role in the physiological plasticity of Antarctic microorganisms, efficiently respond to a lower temperature and freeze-thaw cycles (Singh et al. 2017). Additionally, carotenoids play a role in cell differentiation and regulation during cell cycles.

Several studies reported carotenoid producing bacteria and fungi from low temperature environments (Table 1). Vila et al. (2019) reported 30 bacterial strains capable of carotenoids production from Fildes Peninsula, King George Island, Antarctica. Kim et al. (2015) isolated carotenoid producing Planococcus faecalis from stools of Antarctic penguins. Carotenoid production was reported in heterotrophic bacteria from Antarctica as a strategic tool against ecological stresses (Dieser et al. 2010). The accumulation of C-50 carotenoid (Bacterioruberin and its glycosylated derivatives) observed in psychrotrophic Arthrobacter agilis from an Antarctic sea ice sample. This accumulation of pigments might be responsible for the regulation of cellular membrane fluidity at low temperatures (Fong et al. 2001). Moreover, several polar and non-polar carotenoid pigments produced by Antarctic strains of Sphingobacterium antarcticus and Micrococcus roseus (Chattopadhyay and Jagannadham 2001). Silva et al. (2019) reported carotenoid producing bacterial strains isolated from the Antarctic continent. Three different carotenoids such as zeaxanthin, $\beta$-cryptoxanthin, and $\beta$-carotene were reported from Antarctic bacterium Sphingobacterium antarcticus. Similarly, carotenoid producing coldadapted Penicillium sp was reported in the Himalaya region of India (Pandey et al. 2018). Several carotenoid-producing yeasts were reported in Italian alpine glaciers (Amaretti et al. 2014). Vaz et al. (2011) reported multiple yeasts isolates from Antarctica capable of carotenoid production.

\section{Prodigiosin}

Prodigiosin is a red linear tripyrrole pigment primarily reported from Serratia marcescens (Boger and Patel 1987). Prodigiosin was named after its extraction from Bacillus prodigious later given the name of $S$. marcescens (Gerber 1975). Prodigiosin produces only in later growth stages of bacteria (Harris et al. 2004). Biosynthesis of prodigiosin is controlled by quorum sensing (Thomson et al. 2000). 
Certain proposed eco-physiological roles of prodigiosin are; air diaspora of bacteria (Burger and Bennett 1985), metabolic precursor for $\mathrm{NAD}(\mathrm{P}) \mathrm{H}$ or proline (Hood et al. 1992), light energy storage (Ryazantseva et al. 1995), ion exchange (Seganish and Davis 2005), energy spilling function in S. marcescens (Haddix et al. 2008) and acts as an antimicrobial agent to provide a competitive advantage within communities (Starič et al. 2010). Borić et al. (2011) studied that prodigiosin is protective against UV radiation in Vibrio sp. DSM 14379. Prodigiosin was extracted from psychrotrophic bacterial strain Janthinobacterium lividum isolated from Alaskan soil (Schloss et al. 2010). Shen et al. (2018) reported several red pigment-producing bacterial strains inside deep ice core collected from the Yuzhufeng Glacier, Tibetan Plateau. Centurion et al. (2019) reported genes in Antarctic volcanic island sediments responsible for the biosynthesis of 3-oxoacyl-[acyl-carrying protein] reductase (K00059) enzyme that belongs to the fatty acid synthesis pathway type II associated to the production of prodigiosin.

\section{Melanin}

Melanin is dark in color (brown to dark green, or fully black) and higher molecular weight biological pigment found in hair, feather, skin, eyes, scales, and some interior membranes. Melanin is chemically a polymerized product of phenolic and/or indolic compounds (Tarangini and Mishra 2014). Melanin is further classified into three groups based on structure and color (i) pheomelanins (red or yellow), (ii) eumelanins (black-brown), and (iii) allomelanins (black to dark brown) (Table 2). Due to variations in the occurrence and structure of melanin, its biosynthesis is not from a single route (Solano 2014). Melanin synthesis has been associated in providing resistance against UV- and visible light-irradiations, confrontation the attack of cell wall enzymes, fortification against oxidizing and reducing agents, and acts as an antiviral agent to enhanced the competitive and survival abilities in environmental stresses (Castro-Sowinski et al. 2007; Solano 2014). Melanin is a strong absorber of UV radiations and provides strong protective functions to microbes that's why extreme low temperature ecosystems are suitable habitats for microbial biosynthesis of melanin (Gessler et al. 2014).

In general, melanin pigment is insoluble both in organic and aqueous solvents, however, Kimura et al. (2015) isolated bacteria strain Lysobacter oligotrophicus from the Antarctic environment that produced water-soluble heteropolymer (Lo-melanin). Lo-melanin protects against UV radiation and scavenges ROS. Melanin is commonly present in polar dark septate hyphae, and guards hyphae against low temperatures and play a crucial role in their persistence (Robinson 2001).
Chyizhanska and Beregova (2009) isolated melanin from Antarctic yeasts. An Antarctic fungus, Friedmanniomyces endolithicus produces highly melanized thick-walled cells that protected cells from UV radiation (Onofri et al. 2004). Similarly, Rosa et al. (2009) isolated melanin-producing endophytic fungal strains from the leaves of Deschampsia antarctica and about $80 \%$ were black molds. In the Antarctic rocky deserts, rock-inhabiting fungi produce melanin pigments that protect the cells from extreme cold and heat, polychromatic UV radiations, extreme $\mathrm{pH}$ and osmotic conditions, and provides tolerance towards potentially toxic metals (Selbmann et al. 2015). Melanin was purified from cold-tolerant and oligotrophic bacterium L. oligotrophicus isolated from the Skarvsnes region, East Antarctica (Fukuda et al. 2013). UV-B radiations induced melanogenesis in $L$. oligotrophicus cells, that protected the suspensions of $E$. coli $\mathrm{DH} 5 \alpha$ cells from UV radiations by melanin solutions. In short, melanin biosynthesis by microorganisms can play crucial roles in low temperature environments such as to cope with low temperature, protection against UV radiations, freeze-thaw cycling and desiccation, scavenging ROS. These microbes could be a microbial model for exobiological/astrobiological studies.

\section{Violacein}

Violacein is violet or purple bisindole water-insoluble pigment and first reported from Chromobacterium violaceum from the Amazon River in Brazil (Durán et al. 1953). In nature, violacein protects cells from UV radiations (Füller et al. 2016). Several studies have reported the antibacterial, antiviral, anticancer, antiulcerogenic, antileishmanial, and enzymatic modulation activities of violacein pigments (Duran et al. 2007; Soliev et al. 2011). The maximum UV absorption capacity of violacein is $\lambda=260 \mathrm{~nm}$, which suggests its crucial role in the protection of cells from visible and UV radiations (Marizcurrena et al. 2019). In nature, violacein is associated with biofilm production (Pantanella et al. 2007) and its production is regulated by quorum sensing thus acts as a marker of quorum sensing molecules (Burt et al. 2014). Violacein plays a vital role in protecting bacterial cells from predation (Choi et al. 2015). Apart from several other habitats, violacein has been reported from several low temperature environments. Lu et al. (2009) reported a novel psychrophilic bacterium from Xinjiang glaciers, China, capable of violacein production. Violacein producing psychrophilic Janthinobacterium svalbardensis bacterium was isolated from Glacier, Spirsbergen, Arctic region (Ambrožič et al. 2013). Kim et al. (2012) reported violacein producing psychrophilic bacterium Janthinobacterium sp. from alpine glacier cryoconite. Hakvag et al. (2009) reported violacein producing Collimonas sp. from Arctic coastal water in Trøndelag, Norway. Similarly, Nakamura et al. (2002) reported 
Table 2 Types of pigments from cold-adapted microorganisms, their applications, and chemical structures

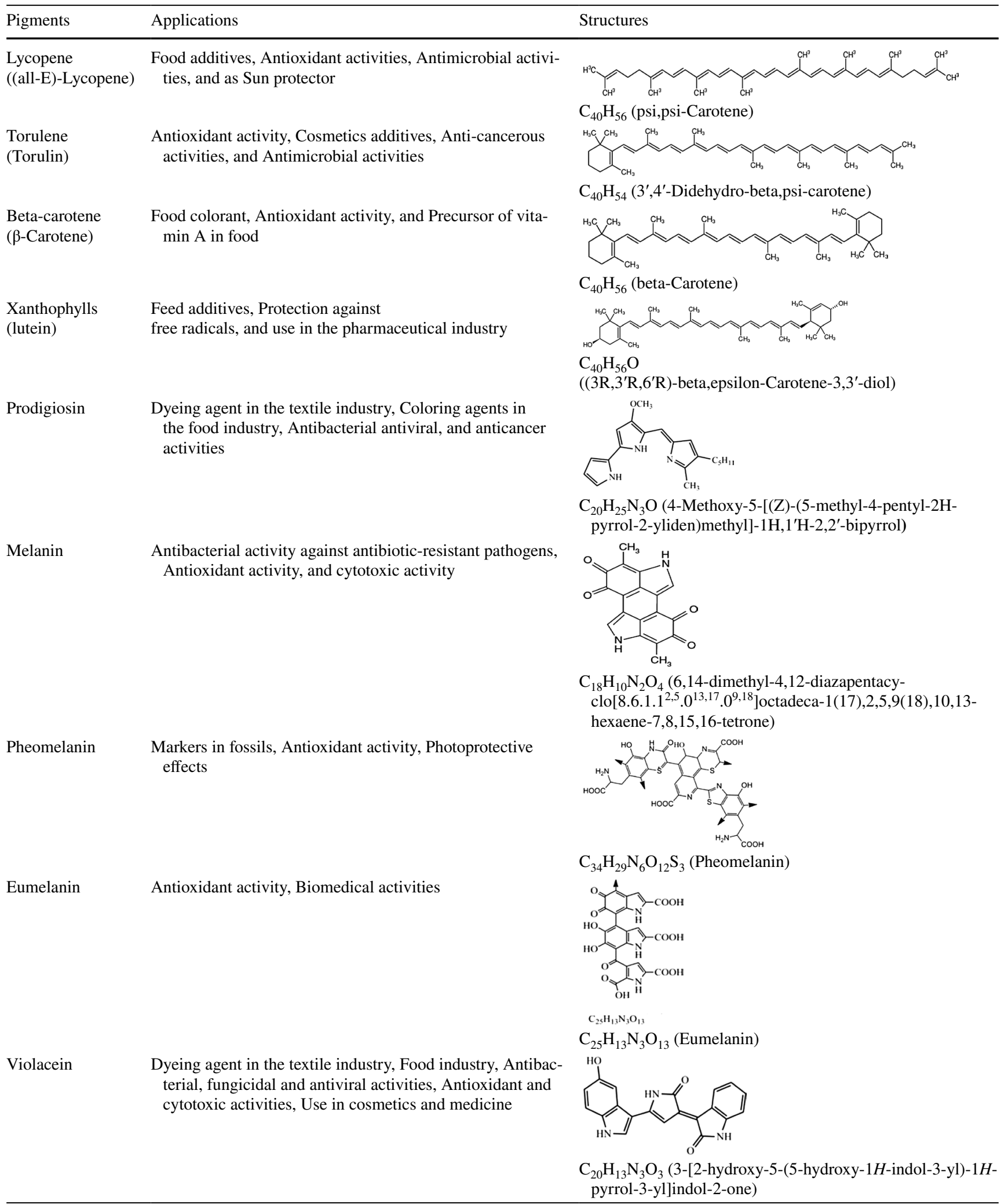


Table 2 (continued)

\begin{tabular}{lll}
\hline Pigments & Applications \\
Indigoidine & As bioindicator, Antimicrobial activities, and the Textile \\
industry as a dyeing agent & Anti-inflammatory and Anti-proliferative drugs, Antioxidant \\
agents, Use in cosmetics & & \\
& &
\end{tabular}

violet pigment-producing psychrotrophic bacterium from the water tank keeping rainbow and exploited its pigment for antibacterial potential. Shivaji et al. (1991) isolated the bacterium of Janthinobacterium genus that produced violacein and further Durán et al. (2007) evaluated the pigments for several therapeutic activities. Mojib et al. (2010) extracted violacein-like purple violet pigment from Janthinobacterium sp. reported from Proglacial Lake Podprudnoye, Schirmacher Oasis, Antarctica that inhibited the growth of Mycobacterium smegmatis and Mycobacterium tuberculosis. At low doses, the same pigment showed activity against methicillin-resistant and multiple drug-resistant clinical strains of Staphylococcus aureus (Huang et al. 2012).

\section{Indigoidine}

Indigoidine is a brilliant blue, water-soluble pigment synthesized by very few microorganisms (Sutthiwong et al. 2014) namely Erwinia chrysanthemi (Reverchon et al. 2002), Phaeobacter sp. (Cude et al. 2012), Streptomyces chromofuscus (Yu et al. 2013) and Vogesella indigofera (Day et al. 2017), and the biological and environmental role of indigoidine is unclear, however, it has been described that this pigment could protect against oxidative stress (Reverchon et al. 2002). Indigoidine also possesses antimicrobial activities as stated in Leisingera isolates (Gromek et al. 2016). Consequently, microbes producing indigoidine could have advantage of competition in the environment due to the antibiotic and antioxidant properties of indigoidine. Furthermore, indigoidine acts as intracellular signaling molecules related to motility (Reverchon et al. 2002; Cude et al. 2012). Additionally, indigoidine provides adaptability to microbial cells such as Vogesella sp. reported from Andean Patagonia in iron-rich environments (Day et al. 2017). Several isolates of Antarctic genus Arthrobacter were reported to produce indigoidine (Sutthiwong et al. 2014). Arthrobacter genus (family Micrococcaceae) are more common in Antarctic surroundings such as sediments and soils (Reddy et al. 2003; Dsouza et al. 2015). Bacteria belong to this genus produce different pigments including blue indigoidine (Sutthiwong et al. 2014). Kobayashi et al. (2007) reported indigoidine production from Shewanella violacea DSS12 a piezophilic and psychrophilic bacterial strain isolated from deep-sea sediments of the Ryukyu Trench. Liao et al. (2019) studied the multipartite genomes and sRNome of Arctic Pseudoalteromonas fuliginea BSW20308 and reported upregulated genes encoding indigoidine biosynthetic.

\section{Scytonemin}

Scytonemin is a secondary metabolite of small hydrophobic alkaloids having yellowish-brown color (Table 2). Cyanobacteria when get exposed to UVA-blue wavelengths, scytonemin was produced (Fleming and Castenholz 2007). Scytonemin and its methoxylated and methylated derivatives are mostly reported in the upper portion of the microbial mats; that could protect the cells from extreme environments, which makes this pigment a potential biomarker molecule for studying the presumed exobiology habitats. Exposure of cyanobacteria to UV radiation produces scytonemin along with several other protective metabolites (Sinha et al. 1998). Therefore, these molecules might have performed a crucial role in Antarctica during the initial life stages on this planet (Dillon and Castenholz 1999). The palaeolimnological investigation that was carried out in 62 east Antarctic lakes revealed that the composition of pigments was different in different depths of lakes and higher scytonemin was reported in shallow lakes. Since cyanobacteria regulate their pigment production, this difference of pigment contents could be due to the light-harvesting ability of pigments at different depths (Sabbe et al. 2004). Several Antarctic cyanobacterial genera that are capable to produce scytonemin are reported in Table 1. 


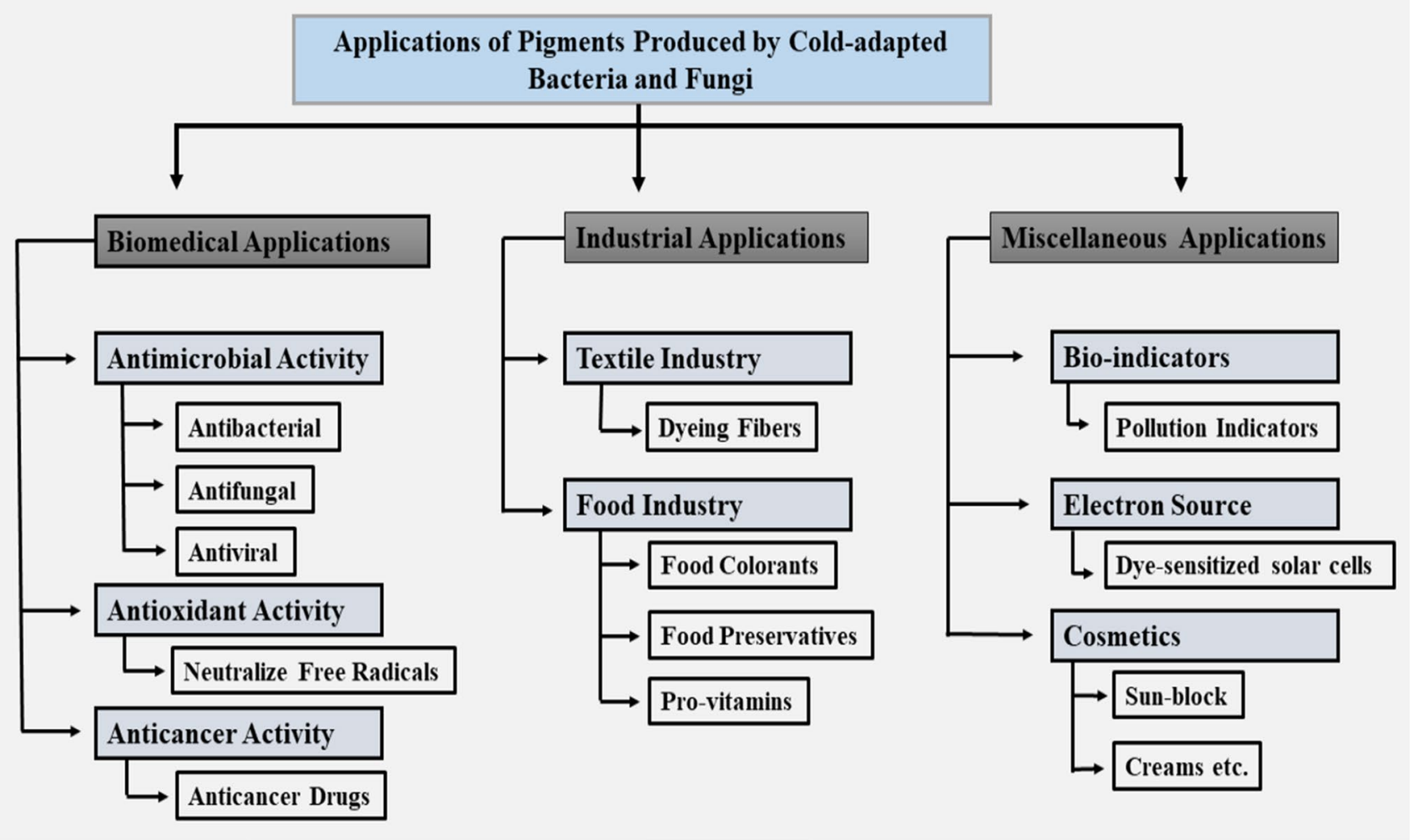

Fig. 2 Schematic representation of the pigments applications obtained from cold-adapted microbes

\section{Applications of microbial pigments}

Versatile pigments produced by microorganisms are more focused during present research due to their extensively observed applications in textile industries, food industries, and biomedical purposes. Global trade of naturally derived pigments has been increased by $29 \%$ and reached 600 million USD from 2007 to 2011 (Tuli et al. 2015). This indicates that the pigments produced by microorganisms would dominate the organic market and pigment industries very soon (Ramesh et al. 2019). Such economic growth and vast applications of pigments rationalize the exploration of new sources of natural pigments. Cryospheric environments might provide the best source for the exploration of novel pigments producing microorganisms. Biotechnological applications of psychrophilic microorganisms remained a dream for decades. However, in the early 1990s researchers started focusing their possible usefulness in genetic bioengineering, food and mining industries (Gounot 1991). Currently, several of these expectations are being confirmed, since psychrophilic microorganisms and their secondary metabolites are now acting as sustainable and priceless resources for biotechnological development. Among other invaluable products, pigments produced by these psychrophilic microorganisms are the center of focus in modern research. Table 1 illustrates the microorganisms isolated from cryospheric environments producing pigments of potential applications in industries (Fig. 2). General applications of microbial pigments are as following.

\section{Industrial applications}

\section{Textile industry}

Textile industries use 1.3 million tons of synthetic dyes and precursors (worth of 23 billion USD) 15\% of which leak as effluents during their use (Venil et al. 2013; Chequer et al. 2013). Unluckily, enough portion of these dyes escape the conventional processes of wastewater treatment and exist as a potentially toxic environmental pollutant with adversities on public health and environment (Ogugbue and Sawidis 2011). Consequently, a great concern exists to replace the synthetic dyes in the textile industry with environmentally friendly dyes. Pigments obtained from microorganisms are environmentally friendly that is considered appropriate for the textile industry (Chadni et al. 2017). Violacein, a multipurpose pigment extracted from C. violaceum is capable of dyeing both natural and synthetic fibers and has gained increasing importance in textiles (Wan et al. 2014; Venil 
et al. 2016). Prodigiosin a bright red pigment from Vibrio sp. is suitable for dyeing a range of fibers including nylon, acrylics, wool, and silk (Alihosseini et al. 2008). Similarly, prodigiosin reported from Serratia sp. BTW J8 was demonstrated to color various fabric types such as chiffon, cotton, pure silk, poplene, century cotton, organdi, dupoil silk, terrycotton, polyester, and nylon (Krishna 2008). The blue pigment indigoidine produced by fungal host Rhodosporidium toruloides possesses potential applications in the dye industry (Wehrs et al. 2019). Pigment extracted from J. lividum shows a bluish-purple color tone on cotton, silk, and wool, while with vinylon and nylon it appears dark blue (Shirata et al. 2000). Likewise, the yellow pigment extracted from Thermomyces exhibited a higher dyeing affinity for silk fabric compared to other fabrics (Poorniammal et al. 2013). Similarly, red and deep blue pigments reported from Streptomyces strains NP2 and NP4 exhibited substantial variations in dyeing ability depending upon fabric materials. For instance, acrylic and polyamide fibers were vibrantly stained, however, cellulose and cotton fibers were weakly stained (Kramar et al. 2014). In the view of such extensive use of microbial pigments in the textile industry could increase their market value; therefore, new microbial sources are crucial to explore for pigment production and cryosphere inhabit broad microbial diversity capable of pigment production.

\section{Food industry}

One important goal in the food industry is to develop foods having an attractive appearance that has been achieved with synthetic dyes. Progressively, food industries are now using natural food colorants, since certain synthetic food colorants have demonstrated adverse health problems after consumption. Due to the shortage of natural food additives resources, their demand is increasing particularly in the food industry (Aberoumand 2011). This demand can be fulfilled by providing a more natural and healthy means of food colors offering a clean and safe tag declaration. Scientists have isolated food-grade pigments from bacterial strains that might provide a natural food colorant having tremendous stability, health safety profile and also act as antioxidants and preservatives (Nigam and Luke 2016). Pigment approval as food color and nutritional supplements greatly depend upon the health safety of consumers and product freshness. Thus, the use of pigmented molecules in food, cosmetics, medicine, and other medical devices is under the control of the Federal Food, Drug, and Cosmetic Act (Chapter VII, Sect. 721) and authorization should be taken before use for the specific time (https://www.fda.gov/).

Several microbial pigments like astaxanthin from Xanthophyllomyces dendrorhous, a red pigment obtained from Monascus sp., $\beta$-carotene produced by Blakeslea trispora, lycopene from Fusarium sporotrichioides and Erwinia uredovora, riboflavin reported from Ashbya gossypii, and Arpink red ${ }^{\mathrm{TM}}$ from Penicillium oxalicum were supplemented in different food items to enhance its appeal (Dharmaraj et al. 2009). For instance, carotenoids obtained from bacteria are used in feed as pro-vitamins and coloring agent in food industries (Nelis and De Leenheer 1991). Carotenoids are studied to be used as coloring agents for soft drinks, cooked sausages, and baked items (Konuray and Erginkaya 2015). It can also protect food from intense light and maintain the food quality by acting as a sunscreen (Chattopadhyay et al. 2008). Spray-dried prodigiosin from $S$. marcescens has been applied effectively as a coloring agent in milk, yogurt, and carbonated drinks (Namazkar and Ahmed 2013). Violacein obtained from bacterial sources has been successfully used in food industries (Dufosse 2018). Canthaxanthin is used in food items such as fish, candy, cheese, fruits, meat, snacks, beverages, wine, and beer. Currently, several pigments obtained from microorganisms are approved and used in foods for several purposes (Nigam and Luke 2016).

\section{Biomedical applications}

\section{Antimicrobial activities}

Infectious diseases are the second major reason for global human deaths and third in developed countries after noncontagious diseases (WHO 2018). In the recent few decades, new drug entry in the market has been decreased and microbial resistance against antibiotics is increasing. This increasing trend of microbial antibiotic resistance amplified the demand for novel antimicrobial agents. As an alternative to antibiotics, several microbial pigments have been successfully evaluated for antimicrobial activities. Umadevi and Krishnaveni (2013) studied pigments extracted from Micrococcus luteus that exhibited inhibitory potential against wound pathogens such as Pseudomonas sp. Klebsiella sp. and Staphylococcus sp. Carotenoids extracted from Holomonas sp. exhibited antimicrobial potential against antibiotic-resistant S. aureus, Klebsiella sp., and Pseudomonas aeruginosa, and ophthalmic S. aureus, Streptococcus pyogens, and E. coli (Ravikumar et al. 2016). Vasanthabharathi et al. (2011) studied the inhibitory potential of crude melanin obtained from Streptomyces against $E$. coli. Pigment extracted from Streptomyces hygroscopicus was effective against pathogens such as vancomycin and methicillin-resistant $S$. aureus, $\beta$-lactamase producing $E$. coli, $P$. aeruginosa and Klebsiella sp. (Berlanga et al. 2000; Selvameenal et al. 2009). Violacein obtained from C. violaceum and J. lividum showed promising antibacterial activities (Durán et al. 2007). Violacein reported from C. violaceum ATCC 12472 showed tremendous antimicrobial activity against $S$. aureus and inhibition of its biofilm formation (Batista and da Silva 
Neto 2017). Similarly, Antarctic bacterial violacein in lower concentrations showed activity against avirulent $M$. tuberculosis (Mojib et al. 2010). A combination of violacein with antibiotics such as kanamycin and cefadroxil minimize the inhibitory concentration of drugs against $S$. aureus (Subramaniam et al. 2014). Additionally, violacein extracted from J. lividum exhibited fungicidal activity against white root rot causing Rosellinia necatrix (Shirata et al. 1997). Prodigiosin obtained from Vibrio ruber DSM 14,379 exhibited bacteriostatic activity against E. coli and Bacillus subtilis (Danevčič et al. 2016). Furthermore, prodigiosin intracellularly produced by $S$. marcescens IBRL USM 84 inhibited the growth of tested bacteria (Ibrahim 2008). Prodigiosin revealed promising antibacterial activity against pathogens such as S. aureus, S. pyogenes, $P$. aeruginosa and Klebsiella pneumoniae (Nwankwo et al. 2017). Pigments extracted from endophytic fungi Monodictysc astaneae demonstrated antibacterial activity against Vibrio cholera, K. pneumoniae, and S. aureus (Visalakchi and Muthumary 2010). Suryawanshi et al. (2017) studied the strong antimicrobial activity of prodigiosin against E. coli, S. aureus, and Candida albicans. Similarly, several prodiginine compounds are reported having fungicidal activities against fungi such as Penicillium, Aspergillus, Candida, and Cryptococcus sp. (Stankovic et al. 2014).

Throughout human history, several viral outbreaks occurred and still occurring such as the Western African Ebola virus epidemic and the recent Coronavirus pandemic COVID-19 accompanied with moderate to high mortality rate. This urge that the discovery of novel antiviral drugs is critically important as many viral infections lack vaccines and effective treatments. Researches showed some initial successes using microbial pigments as antiviral agents. Violacein possesses antiviral potentials against poliovirus, simian rotavirus SA II, and herpes simplex virus (HSV) (Durán et al. 2007). In vitro effects of violacein are also evaluated against Acquired Immuno Deficiency Syndrome (AIDS) related lumphoma (Duran et al. 1996). Andrighetti-Fröhner et al. (2003) studied the antiviral activities of bacterial extracted violacein and inhibition of HSV-1 and Poliovirus-2 (PV-2) replication was observed. Similarly, an in-silico examination of prodigiosin by targeting proteins of Human Immunodeficiency Virus (HIV), Hepatitis B virus (HBV), influenza A virus (H1N1) and Hepatitis C virus (HCV) was performed (Suba et al. 2013). The outcome proposed potential antiviral activities of prodigiosin pigment against all tested viruses excluding $\mathrm{HCV}$, where no binding interactions with active sites were reported. Moreover, compounds of quinone such as naphthoquinones, anthraquinones, and benzoquinones possess strong antiviral potential (Koyama 2006; Gessler et al. 2013). Several compounds obtained from Phoma species exhibited the inhibition of HIV integrase (Rai 2009).
Phenazine compounds extracted from Streptomyces and Pseudomonas species have been demonstrated promising antiviral activities (Schneemann et al. 2011). Therefore, microbial pigments are potential agents to administered as a novel source of medications against pathogens.

\section{Antioxidants activity}

The rise of free radicals inside the body increases the risks of chronic diseases such as diabetes, autoimmune disorders, and cancer (Phaniendra et al. 2015). To evade this, antioxidant compounds are used which donate electrons to free radicals and neutralize them to protect cellular damage (Lobo et al. 2010). Antioxidants are obtained either from natural or synthetic sources, however, synthetic antioxidants are losing demand due to possible side effects on the human body (Ahmed et al. 2013). Therefore, microbial-based antioxidants are gaining ground in the pharmaceutical industry. Pigments from microorganisms such as carotenoid, xanthomonadin, and naphthaquinone showed antioxidant potential (Tuli et al. 2015). Carotenoids extracted from Antarctic bacterium Pedobacter exhibited solid antioxidant activity with protection against oxidative harm (Correa-Llantén et al. 2012). Osawa et al. (2010) demonstrated promising antioxidant abilities of rare C-50 carotenoids such as sarcinaxanthin monoglucoside, sarcinaxanthin diglucoside, and sarcinaxanthin, reported from a halophilic bacterium Micrococcus yunnanensis. Moreover, Shindo and Misawa. (2014) extracted rare and new carotenoids from the novel bacterial isolates and these pigments exhibited strong antioxidant activities. Similarly, flexirubin (red carotenoid), obtained from Fontibacter flavus showed antioxidant activity against 2, 2-diphenyl1-picryl-hydrazyl-hydrate (DPPH), nitric oxide, hydroxyl radical, and inhibition of lipid peroxidation (Prabhu et al. 2013). Additionally, melanin reported from fungal isolate Streptomyces glaucescens (El-Naggar and El-Ewasy 2017) and anthraquinones obtained from endophytic Stemphylium lycopersici ( $\mathrm{Li}$ et al. 2017) were characterized as antioxidants. Another valuable bacterial pigment violacein obtained from $C$. violaceum exhibited antioxidant protection in gastric ulceration (Antonisamy and Ignacimuthu 2010). Violacein can also safeguard the cellular lipid membranes from peroxidation due to hydroxyl radicals (Stafsnes and Bruheim 2013). Several studies reported melanin obtained from Pseudomonas sp, S. glaucescens NEAE-H, and Bifidobacterium infantis were found antioxidant agents (Huang et al. 2011; Tarangini and Mishra 2014; Zerrad et al. 2014). These reports recommend that pigments obtained from microorganisms could be used as antioxidant agents to prevent several chronic diseases. 


\section{Anticancer activity}

Cancer is one of the most lethal diseases in human history. Till now, several anticancer medicines have been designed and are in the stage of the clinical trial. However, success limitations, adverse effects, and resistance towards treatments are the major challenges in cancer treatment (Foo and Michor 2014). Therefore, search for novel and effective anticancer agents with least or no side effects is of great interest. Several kinds of research conducted on microbial pigments as anticancer agents exhibited promising results. One such study on novel red pigment extracted from Athrobacter sp. G20 exhibited anticancer potential against the oesophageal cancer cell line (KYSE30) (Afra et al. 2017). A yellow pigment reported from Streptomyces griseoaurantiacus demonstrated strong cytotoxic activity against cervical cancer cells (HeLa) and HepG2 and resulted in a lower number of viable cells (Prashanthi et al. 2015). Carotenoid extracted from Kocuria sp. QWT-12 revealed anticancer potential against breast cancer cell lines and lung cancer cells (Rezaeeyan et al. 2017). Similarly, carotenoids from Haloferax volcanii killed $53.52 \%$ of human liver carcinoma cell lines (Sikkandar et al. 2013). Black melanin extracted from $S$. glaucescens exhibited significant cytotoxic activity against the HFB4 skin cancer cell line (El-Naggar et al. 2017). Dihydroxyphenylalanine melanin obtained from Streptomyces sp. MVCS6 exhibited dose-response anticancer activity against the cervical cancer cell line (Sivaperumal et al. 2015). Wang et al. (2012) studied prodigiosin obtained from Pseudoalteromonas sp. having a cytotoxic effect against U937 leukemia cells. Strong anticancer activity of prodigiosin obtained from $S$. marcescens is reported against human cervical cancer cells and laryngeal cancer cells (Maheswarappa et al. 2013). Cheng et al. (2017) evaluated the influence of prodigiosin reported from Vibrio sp. against human oral squamous carcinoma cells (OSCC) and found that the prodigiosin arrests their cell cycle. Recently, prodigiosin showed a reduction of the intracellular signaling pathway during the cell cycle and induced apoptosis in lung cancer cells and also showed in vivo tumoricidal activity (Chiu et al. 2018). Interestingly, a combination of natural compounds with chemotherapy drugs enhance its efficacy and reduce their toxicity. Prodigiosin when combined with paclitaxel against MCF7 breast cancer cells (Ho et al. 2009) and doxorubicin (Dox) against OSCC cell lines (Lin and Weng 2018) an efficient synergistic effect was reported. Violacein obtained from $C$. violaceum induced cytotoxicity and apoptosis activity in Chinese hamster lung fibroblast V79 cells (Melo et al. 2000) and leukemia cell lines (Melo et al. 2003; Ferreira et al. 2004). Additionally, violacein also increased apoptosis in colon cancer cells (Kodach et al. 2017) and human breast cancer cells (Alshatwi et al. 2016). Several anthraquinone derivatives from marine-derived fungi are capable of tumor cell inhibition (Fouillaud et al. 2016). Anthraquinone derivatives from fungus Alternaria sp. have been studied for anticancer activity against human breast cancer cell lines (Huang et al. 2011). In light of the above studies, the microbial pigment could be potential chemotherapeutic agents for cancer treatment.

\section{Bio-indicators}

Bioindicator bacteria are bacteria that can monitor environmental health and reveal the qualitative status of the environment by changing their behavior and specific physiological characteristics (Parmar et al. 2016). One such change is the production and/or alteration of certain pigments in pigmented bacteria that could be effectively used as bioindicators. For instance, violet pigmented bacteria along with Sporocytophaga and Flexibacter species were bioindicators of polluted drinking water (Schindler and Metz 1989). Indigoidine production by Vogesella indigofera is suppressed by $\mathrm{Cr}^{6+}$ in a concentration-dependent manner which is an indication of chromium concentration and toxicity in the environment (Gu and Cheung 2001). The existence of carotenoid in Lecanoraceae lichens has been confirmed to depend upon the pollution level in the atmosphere of the surrounding environment, where they reside by analyzing the carotenoid content of fungi acting as bioindicator (Ibarrondo et al. 2016). Using the gene clusters encoding prodigiosin biosynthesis in S. marcescens and violacein biosynthesis from C. violaceum demonstrate the implementation of reporter systems for the signal of biosynthetic gene expression (Domröse et al. 2017). The participation of melanin pigments in protection from environmental stress like UV radiation and potentially toxic metals is regarded as a bioindicator due to its overproduction in adverse conditions (Egorova et al. 2011). Similarly, cyanobacteria naturally present in water sources could act as excellent bioindicators for heavy metals, since in the presence of heavy metals, the carotenoids content in these cyanobacteria reduces (Wong and Teo 2014).

\section{Miscellaneous applications}

Pigment-producing microbes in cryospheric environments could act as a potential source of electrons and may be employed for developing dye-sensitized solar cells (DSSC) that would be a potential alternative of conventional photovoltaic-silicon cells based. Consequently, DSSC might signify a remarkable alternative that could somewhat solve the energy requirement at Antarctic regions. For instance, the orange-xanthophyll pigment extracted from UVCresistant Hymenobacter sp. (Marizcurrena et al. 2017) was exploited for DSSC development (Órdenes-Aenishanslins 
et al. 2016; Montagni et al. 2018). Similarly, Pezzella et al. (2019) studied the eumelanin and graphene integration and observed improved electrical conductivity which shows the scope of eumelanin in bioelectronics. Bacterial pigments can be used as biodegradable ink on plastic materials. The hue and chroma values are observed in red and violet color suggestive of prodigiosin and violacein pigments isolated from $S$. marcescens and $C$. violaceum, respectively (Venil et al. 2017). Astaxanthin from radioresistant Deinococcus sp. exhibiting radio-protective and antioxidant activities can be incorporated in cosmetics including sunblock and sunscreen (Sajjad et al. 2017). The bacterial pigments prodigiosin and violacein exhibiting antioxidant and antimicrobial activities represent a new paradigm for sunscreens that utilize substances of biological origin (Suryawanshi et al. 2015). These pigments can be a potential ingredient in a range of commercial sunscreen products. Indigoidine can be used as an organic semiconductor with numerous applications in carbon dioxide capture devices, electrochemical cells, super capacitors, batteries, etc. (Yumusak et al. 2019).

\section{Conditions optimization for pigment production}

Microbial survival depends upon a wide range of nutrients and physicochemical factors that further control the production of metabolites illustrated in Fig. 3. In general, microbes could adapt three routes for metabolites production. These routes are; natural production of metabolites; metabolites production under strained environmental conditions; and stimulation of metabolites production by supplementing certain nutritional requirements along with physiological parameters (Ramesh et al. 2019). Detail description of pigment extraction has been reviewed from microalgae (Amaro et al. 2016), yeast (Yurkova et al. 2008), fungi (Rai 2009; Ahmad et al. 2015), and bacteria (Stafsnes and Bruheim 2013). Psychrophilic microorganisms produce several pigments to cope with the life-endanger challenges in the cryosphere. Cold-adapted algae are extensively studied for pigment production, however, little is known about the pigment production potential of cold-adapted bacteria and fungi due to several reasons such as their unique physiological and nutritional requirements, slow and unseen growth in the environment, and less exploration in axenic form. To obtain pigments from cold-adapted microorganisms identifying suitable substrates and evaluation of physicochemical factors are essential for better growth and higher pigment yield.

Pigment production takes place intracellular or/and extracellular depending on $\mathrm{pH}$, temperature, light, several media constituents (Buck et al. 1974), sampling sites and cultivation conditions (Stafsnes and Bruheim 2013). Under laboratory conditions, the microbial pigment production is ephemeral in nature. However, higher yield could be obtained if several factors such as medium components and environmental parameters are optimized in an understandable way (Ramesh et al. 2019). Such as a study conducted by Pandey et al. (2018) stated that additional supplementation of maltose as a source of carbon in potato dextrose broth boosted the orange pigment production by a psychrophilic strain of Penicillium sp. followed by fructose and glucose, however, supplementation of lactose inhibited this production. Pandey et al. (2018) found that extra nitrogen source could not enhance the pigment production, however, minerals salts like $\mathrm{MgSO}_{4}$ and $\mathrm{KH}_{2} \mathrm{PO}_{4}$ can enhance the production of pigment. Maximum pigment production was observed in Monascus sp. supplemented with maltose (Omamor et al. 2008). Pradeep and Pradeep (2013) reported maximum pigment production from Fusarium moniliforme by supplementing glucose in the medium. In the case of filamentous fungi, Carbon/Nitrogen $(\mathrm{C} / \mathrm{N})$ ratio is extremely essential in pigment production (Gmoser et al. 2017). A decrease in pigment production was reported by Cho et al. (2002) and Gunasekaran and Poorniammal (2008) during a higher $\mathrm{C} / \mathrm{N}$ ratio. Similarly, high phosphate concentration and acidity caused the reduction of pigment production and a trace amount of sulfate vitiate pigment production (Reichenbach et al. 1974). Singgih et al. (2015) studied Neurospora intermedia $\mathrm{N}-1$ for carotenoid production in the presence of maltose $(2 \% \mathrm{w} / \mathrm{v})$ as a carbon source. Moreover, minerals salts having different cations were found to improve the production of pigments (Pradeep and Pradeep 2013). Organic acid produced by Monascus ruber inhibits pigment production (Hajjaj et al. 2000). The addition of certain substrates such as wheat, rice meals, and light stimulation enhanced carotenoid production in yeasts and fungi (De Carvalho et al. 2014). ZoBell and Upham (1944) reported an increase in pigment production when bacteria were cultured in seawater supplemented with neopeptone, bacto-tryptone, and beef extract at $4{ }^{\circ} \mathrm{C}$. Ghosh et al. (2007) reported that methanol acted as a sole carbon source induced the production of pink pigment in Acinetobacter wofii. The yellow-green pigment was produced by Pseudomonas fluorescens supplemented with succinate as a sole carbon source, while this production was stopped with the addition of malic and citric acids as substrate (Margalith 1992). Moreover, the influence of light and dark on pigment production was studied and Myxococcus xanthus, Mycobacterium marinum, Rhodotorula glutinis, and Dacryopinax spathularia produced carotenoids during the presence of light. $S$. marcescens produced red pigment on solid peptone-glycerol agar plates, and unable to produce pigment in liquid medium except when supplemented with silica gel (Yamashita et al. 2001). Chen et al. (2013) reported that the prodigiosin production was enhanced when peptone and starch were supplemented as a source of carbon and calcium alginate beads were added as 
a porous carrier. Similarly, Lu et al. (2009) reported sucrose and casein as best carbon and nitrogen sources, respectively, for violacein production by J. lividum XT1 bacteria reported from the glacier in Xinjiang China.

To obtained higher pigment yield, $\mathrm{pH}$ and temperature optimization are essential as they affect the metabolic growth and physical activities of microorganisms. Being cold-adapted organisms, the temperature is a vital factor to be optimized for pigment production. Pandey et al. (2018) reported maximum pigment production at low temperature $\left(15^{\circ} \mathrm{C}\right)$ and acidic condition $(\mathrm{pH} 5)$ by Penicillium sp. Chattopadhyay et al. (1997) studied Antarctic psychrotrophic bacterium $M$. roseus that produced higher carotenoid pigment at $5{ }^{\circ} \mathrm{C}$ compared to $25^{\circ} \mathrm{C}$. Similarly, Lu et al. (2009) reported an optimal temperature of $15^{\circ} \mathrm{C}$ for violacein production by psychrotrophic bacteria. M. tuberculosis produced carotenoid pigments under acidic stress (pH 5-6) (Saviola 2014), and different pigment production was reported in other Mycobacterium species (Robledo et al. 2011). Overproduction of pigment at lower temperatures shows the phenomenon of ecological resilience among cold-adapted microorganisms that combat the deadly environmental conditions. Similarly, enhancement of pigment production below optimum temperature range could be an adapting reaction that compensates the downregulation of metabolic processes at low temperatures (Gmoser et al. 2017). Several genes are responsible for the biosynthesis of pigments in microorganisms. To enhance the pigment production mutagens such as UV light, 1-methyl-3-nitro1-nitrosoguanidine, and ethyl methanesulfonate were used in Haematococcus pluvialis and microwave in S. marcescens (Nigam and Luke 2016), which shows these mutagens could enhance the pigment yield when used precisely. In addition, alteration in genes (knockout or promotion of genes) and mutagenesis practices can increase the pigment production (Venil et al. 2014). Different substrates such as tryptophan, phenylalanine, tyrosine, and several physicochemical parameters can efficiently stimulate pigment production by microorganisms.

Essential pigments from fungal strains can be obtained under optimum growth conditions by solid, semi-solid, and submerged fermentation (Vendruscolo et al. 2010; Akilandeswari and Pradeep 2016) using a diverse range of sustainable substrates (Gupta and Aggarwal. 2014). However, parameters such as $\mathrm{pH}$, temperature, agitation, aeration, and culture medium directly influence the production of pigment and should be kept at an optimized level (Medentsev et al. 2005). Moreover, several solvents such as acetone, chloroform, cyclohexane, acetonitrile, ethanol, dichloromethane, pyridine, hexane, and water are used to extract fungal pigments. The solvent choice is crucial for pigment extraction and depends upon the polarity of the studied molecules. After extraction and purification of pigments, it should be handled carefully and must be kept under optimum

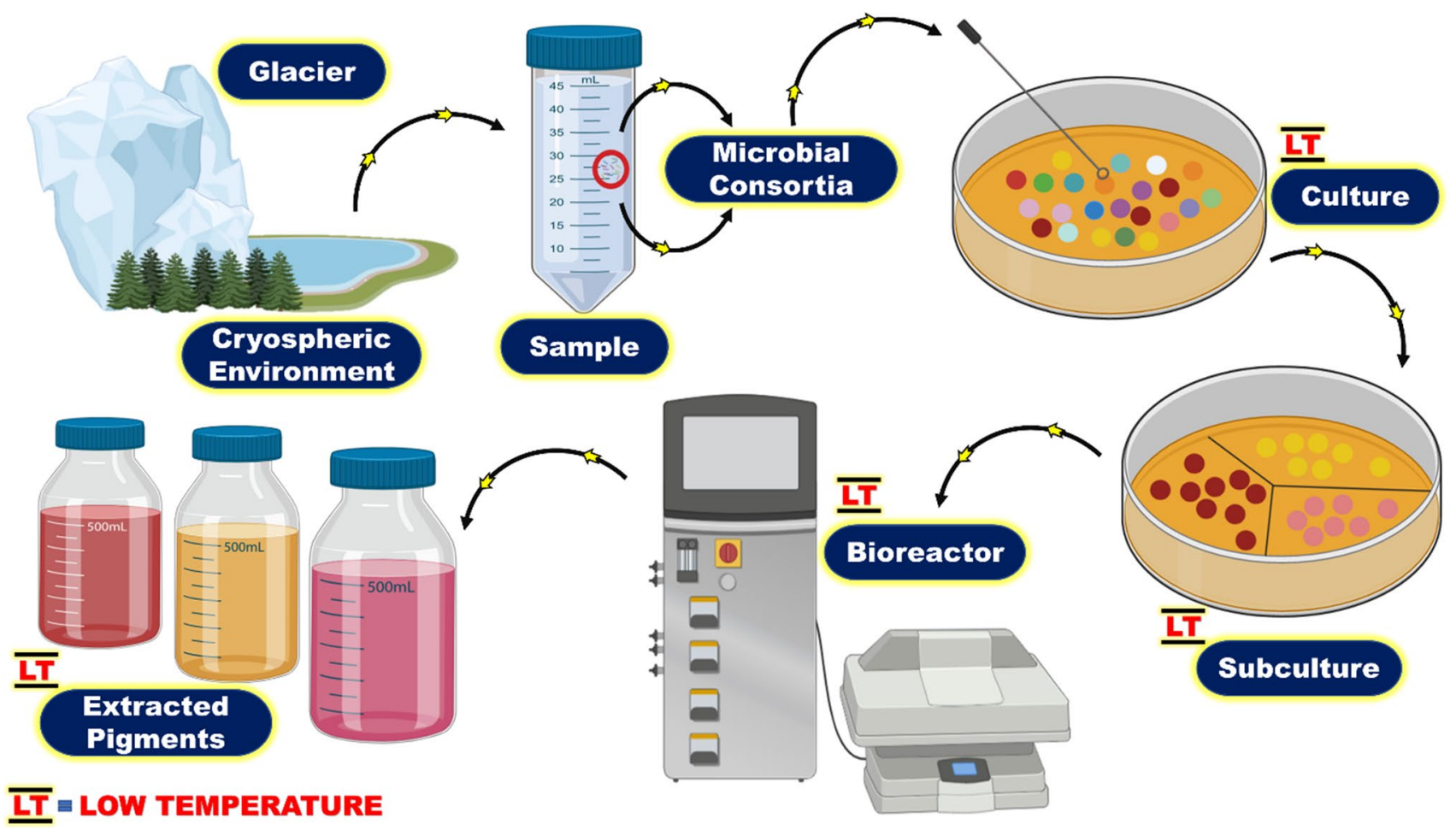

Fig. 3 Schematic representation of pigment extraction from cold-adapted microbes at low temperature 
temperature, and $\mathrm{pH}$ to preserve its original colorimetric characteristics. Pigment storage in dry powder form is more preferable because of its higher stability and low water activity (De Carvalho et al. 2014).

\section{Challenges in pigments obtained from psychrophiles}

Antarctic region and the adjacent Southern Ocean is the rich source of psychrophilic microorganisms capable of pigment production. However, in 2014 the bioprospection is defined during XXXVII Antarctic Treaty Consultative Meeting held in Brasilia. According to this definition, bioprospection is "any activity of search, identification, description, collection, survey, monitoring, cultivation, replication, or any other scientific investigation processes, performed on indigenous biological species with the initial intention to consider potential industrial or commercial derived products or applications, notably through the development of patentable material or process." According to this definition, research curiosity on the biological resources of Antarctica is growing for commercial use. However, several reports highlighted that due to the lack of clear governing and ownership rules for these resources causes appropriation by those who discover it and subsequently develop patent (UNU-UNEP 2009; Jabour 2010; UNEP 2012; Puig-Marcó 2014). In 2008, Antarctic Treaty Committee launched an online database for bioprospecting in Antarctica that provides up-to-date information about bioprospecting in Antarctica. This database also provides information about commercialized products obtained from biological samples indigenous to Antarctica. The records in the database contained many patents related to microbial metabolites having potential biotechnological applications (UNEP Report 2012). The increase in patents shows that Antarctic microorganisms are a precious source of marvelous potential profits. However, one of the leading challenges is the assurance of sustainable exploitation of indigenous biological resources of Antarctica which is yet to decide that how positive benefits of bioprospecting could achieve without inducing major damage to the indigenous environment. Since the uncontrolled prospecting actions that would include logistical labors to reach the biological resources and their definite outcomes could make the process unsustainable and compromise the indigenous microbial diversity (Hughes et al. 2015). In addition, the commercial based research activities and their secrecy could compromise the main pillar of the Antarctic Treaty System (Article III), viz., the unrestricted cooperation and free exchange of information among all parties (Yarzábal et al. 2016). Furthermore, the emerging profitable interest in biological resources raised several key policies, moral and ethical queries: Who would be the owner of these biological resources? How should they be exploited and used? And whom should be benefited and to what extent? Although, few of these questions are included in the 2014 SCAR1-sponsored Antarctic and Southern Ocean Horizon Scan (Kennicutt et al. 2014, 2015). However, several current uncertainty and absence of policies for these biological resources should be addressed to the territorial and commercial sensitivities to agree upon common agreement to protect the local environment. For instance, the Nagoya protocol that entered into force in October 2014 by over 70 countries under international law for the fair and equitable sharing of benefits derived from the utilization of genetic resources (Smith et al. 2017). Like Nagoya protocol, countries should be placed under an obligation to establish legislative, administrative and/or political measures regarding the access to common cold reservoirs such as Arctic and Antarctic. This will aim to provide equal chances of obtaining common cold resources for commercial or academic development by a country or organization. Moreover, to commercialize any kind of microbial pigments, huge investment along with research work for characterization, optimization processes, possible toxicological testing, regulatory approval, and penchant by the consumers are greatly essential (Ahmad et al. 2015; Dufossé et al. 2016; Carvalho et al. 2016). Similarly, optimized fermentation conditions, design and type of bioreactor to achieve desired productivity of microbial pigments (Venil et al. 2014) along with the downstream processing of product purification are quite essential to be considered especially for microorganisms from unusual environments such as cryosphere. Therefore, widespread research is essential to convey the microbial pigments from laboratories to markets, since its demand is higher than supply.

\section{Conclusion}

The demand for natural pigments obtained from microorganisms is now increasing due to the adverse effects causing by synthetic dyes. Therefore, new potential sources are crucial to explore for pigment-producing microorganisms. One such environment is the cryosphere which inhabits microorganisms that produce natural pigments as a protective shield against life-endangered ecological stresses. Exploration of these microorganisms would certainly provide promising sources of novel pigmented molecules having wider biotechnological applications. These unexplored microbes especially novel species could be the potential source for pigments that could be used to develop novel drug compounds as well as in the textile and food industries. Efforts should be done to produce cost-effective production of pigments from these microbes by optimization, and strain improvement through genetic engineering to get rid of toxic synthetic dyes. Sustainable exploitation of these biological 
resources from the cryosphere should be focused to prevent environmental disruption. Several cryospheric environments such as Antarctica should be considered a common legacy for mankind and the international community should declare a clear ethical and moral policy for certain questions including possession of these resources. It is obvious that due to unique qualities, the applications of these pigments obtained from cold-adapted microorganisms would be broader and will start many newer domains in biotechnology.

Acknowledgements This study was supported by the second Tibetan Plateau Scientific Expedition and Research Program (STEP) (2019QZKK0605), the Strategic Priority Research Programme of the Chinese Academy of Sciences, Pan-Third Pole Environment Study for a Green Silk Road (Pan-TPE) (XDA20040501), the National Natural Science Foundation of China (Grant 41630754). Wasim Sajjad is supported by a PIFI Fellowship from the Chinese Academy of Sciences (2020PC0052).

\section{Compliance with ethical standards}

Conflict of interest The authors declare that they have no conflict of interest.

\section{References}

Aberoumand A (2011) A review article on edible pigments properties and sources as natural biocolorants in foodstuff and food industry. WJDFS 6(1):71-78

Afra S, Makhdoumi A, Matin MM, Feizy J (2017) A novel red pigment from marine Arthrobacter sp. G20 with specific anticancer activity. J Appl Microbiol 123(5):1228-1236

Agogué H, Joux F, Obernosterer I, Lebaron P (2005) Resistance of marine bacterioneuston to solar radiation. Appl Environ Microbiol 71:5282-5289

Ahmad WA, Venil CK, Aruldass CA (2015) Production of violacein by Chromobacterium violaceum grown in liquid pineapple waste: current scenario. In: Liong MT (ed) Beneficial microorganisms in agriculture, aquaculture and other areas, microbiology monographs, 29. Springer, Berlin, pp 45-58

Ahmed N, Singh J, Mudasir MA, Kour H, Gupta P, Chauhan H (2013) Naturally occurring preservatives in food and their role in food preservation. Int J Pharm Bio Sci 4:22-30

Akilandeswari P, Pradeep BV (2016) Exploration of industrially important pigments from soil fungi. Appl Microbiol Biotechnol 100:1631-1643

Alihosseini F, Ju KS, Lango J, Hammock BD, Sun G (2008) Antibacterial colorants: characterization of prodiginines and their applications on textile materials. Biotechnol Prog 24(3):742-747

Alija AJ, Sommerburg O, Langhans CD, Siems W, Eckl PM (2005) Cyto- and genotoxic potential of beta-carotene and cleavage products under oxidative stress. BioFactors 24:159-163

Alshatwi AA, Subash-Babu P, Antonisamy P (2016) Violacein induces apoptosis in human breast cancer cells through up regulation of BAX, p53 and down regulation of MDM2. Exp Toxicol Pathol 68:89-97

Amaretti A, Simone M, Quartieri A et al (2014) Isolation of Carotenoid-producing Yeasts from an Alpine Glacier. Chem Eng Trans 38:217-222
Amaro HM, Sousa-Pinto I, Malcata FX, Guedes AC (2016) Microalgae as a source of pigments extraction and purification methods. In: Leo MLN (ed) Marine microorganisms extraction and analysis of bioactive compounds. CRC Press, Boca Raton, pp 99-128

Ambrožič Avguštin J, Žgur Bertok D, Kostanjšek R, Avguštin G (2013) Isolation and characterization of a novel violacein-like pigment producing psychrotrophic bacterial species Janthinobacterium svalbardensis sp. nov. Anton Van Leeuwen 103:763-769

Andrighetti-Fröhner CR, Antonio RV, Creczynski-Pasa TB et al (2003) Cytotoxicity and potential antiviral evaluation of violacein produced by Chromobacterium violaceum. The Memórias do Instituto Oswaldo Cruz 98:843-848

Anesio AM, Laybourn-Parry J (2012) Glaciers and ice sheets as a biome. Trends Ecol Evol 27:219-225

Anesio AM, Lutz S, Chrismas NA, Benning LG (2017) The microbiome of glaciers and ice sheets. NPJ Biofilms Microb 3(1):1-11

Antonisamy P, Ignacimuthu S (2010) Immunomodulatory, analgesic and antipyretic effects of violacein isolated from Chromobacterium violaceum. Phytomedicine 17:300-304

Arcangeli C, Cannistraro S (2000) In situ Raman microspectroscopic identification and localization of carotenoids: approach to monitoring of UV-B irradiation stress on Antarctic fungus. Biopolymers 57:179-186

Arcangeli C, Zucconi L, Onofri S, Cannistraro S (1997) Fluorescence study on whole Antarctic fungal spores under enhanced UV irradiation. J Photochem Photobiol B 39(3):258-264

Arcangeli C, Yu W, Cannistraro S, Gratton E (2000) Two-photon autofluorescence microscopy and spectroscopy of an Antarctic fungus: a new approach for studying the effects of UV-B irradiation. Biospectroscopy 57:218-225

Bakermans C, Tollaksen SL, Giometti CS et al (2007) Proteomic analysis of Psychrobacter cryohalolentis K5 during growth at subzero temperatures. Extremophiles 11:343-354

Bar Dolev M, Bernheim R, Guo S et al (2016) Putting life on ice: bacteria that bind to frozen water. J R Soc Interface. https://doi. org/10.1098/rsif.2016.0210

Barahona S, Yuivar Y, Socias G et al (2016) Identification and characterization of yeasts isolated from sedimentary rocks of Union Glacier at the Antarctica. Extremophiles 20:479-491

Barauna RA, Freitas DY, Pinheiro JC et al (2017) A proteomic perspective on the bacterial adaptation to cold: integrating OMICs data of the psychrotrophic bacterium Exiguobacterium antarcticum B7. Proteomes. https://doi.org/10.3390/proteomes5010009

Batista JH, da Silva Neto JF (2017) Chromobacterium violaceum pathogenicity: updates and insights from genome sequencing of novel Chromobacterium species. Front Microbiol 8:2213

Becker-Hapak M, Troxtel E, Hoerter J, Eisenstark A (1997) RpoS dependent overexpression of carotenoids from Erwinia herbicola in OXYR-deficient Escherichia coli. Biochem Bioph Res Co 239:305-309

Benforte FC, Colonnella MA, Ricardi MM et al (2018) Novel role of the LPS core glycosyltransferase WapH for cold adaptation in the Antarctic bacterium Pseudomonas extremaustralis. PLoS ONE 13(2):e0192559. https://doi.org/10.1371/journal.pone.0192559

Berlanga M, Ruiz N, Hernandez-Borrell J et al (2000) Role of the outer membrane in the accumulation of quinolones by Serratia marcescens. Can J Microbiol 46:716-722. https://doi.org/10.1139/ w00-052

Boger DL, Patel M (1987) Total synthesis of prodigiosin. Tetrahedron Lett 28:2499-2502

Borić M, Danevčič T, Stopar D (2011) Prodigiosin from Vibrio sp. DSM 14379; a new UV-protective pigment. Microb Ecol 62(3):528 
Bowman JP, Brown MV, Nichols DS (1997) Biodiversity and ecophysiology of bacteria associated with Antarctic sea ice. Antarct Sci 9(2):134-142

Buck JD (1974) Effects of medium composition on the recovery of bacteria from sea water. J Exp Mar Biol Ecol 15:25-34

Burger SR, Bennett JW (1985) Droplet enrichment factors of pigmented and nonpigmented Serratia marcescens: possible selective function for prodigiosin. Appl Environ Microbiol 50:487-490

Burt SA, Ojo-Fakunle VT, Woertman J, Veldhuizen EJ (2014) The natural antimicrobial carvacrol inhibits quorum sensing in Chromobacterium violaceum and reduces bacterial biofilm formation at sub-lethal concentrations. PLoSOne 9(4):e93414

Butler MJ, Day AW (1998) Fungal melanins. Can J Microbiol 44:1115-1136

Caruso C, Rizzo C, Mangano S et al (2018) Production and biotechnological potential of extracellular polymeric substances from sponge-associated Antarctic bacteria. Appl Environ Microbiol. https://doi.org/10.1128/AEM.01624-17

Carvalho JC, Bicas JL, Fernández DER et al (2016) Natural colorants from microorganisms. In: Bicas JL, Maróstica MR, Pastore GM (eds) Biotechnological production of natural ingredients for food industry, 1st edn. Bentham Science Publishers, Sharjah, pp 288-321

Castro-Sowinski S, Matan O, Bonafede P, Okon Y (2007) A thioredoxin of Sinorhizobium meliloti CE52G is required for melanin production and symbiotic nitrogen fixation. Mol Plant Microbe In 20:986-993

Cavicchioli R, Charlton T, Ertan H et al (2011) Biotechnological uses of enzymes from psychrophiles. Microb Biotechnol 4(4):449-460

Centurion VB, Delforno TP, Lacerda-Júnior GV et al (2019) Unveiling resistome profiles in the sediments of an Antarctic volcanic island. Environ Pollut 255:113240

Chadni Z, Rahaman MH, Jerin I et al (2017) Extraction and optimisation of red pigment production as secondary metabolites from Talaromyces verruculosus and its potential use in textile industries. Mycology 8:48-57. https://doi.org/10.1080/21501 203.2017.1302013

Chattopadhyay M, Jagannadham M (2001) Maintenance of membrane fluidity in Antarctic bacteria. Polar Biol 24(5):386-388

Chattopadhyay MK, Jagannadham MV, Vairamani M, Shivaji S (1997) Carotenoid pigments of an antarctic psychrotrophic bacteriumMicrococcus roseus: temperature dependent biosynthesis, structure, and interaction with synthetic membranes. Biochem Biophys Res Commun 239(1):85-90

Chattopadhyay P, Chatterjee S, Sen SK (2008) Biotechnological potential of natural food grade biocolorants. Afr J Biotechnol 7(17):2972-2985

Chen WC, Yu WJ, Chang CC et al (2013) Enhancing production of prodigiosin from Serratia marcescens C3 by statistical experimental design and porous carrier addition strategy. Biochem Eng J 78:93-100

Cheng MF, Lin CS, Chen YH et al (2017) Inhibitory growth of oral squamous cell carcinoma cancer via bacterial prodigiosin. Mar Drugs 15:224

Chequer FD, de Oliveira GAR, Ferraz ERA et al (2013) Textile dyes: dyeing process and environmental impact. Eco-friendly Textile Dye Finish 6:151-176

Chiu WJ, Lin SR, Chen YH et al (2018) Prodigiosin-emerged PI3K/ Beclin-1-independent pathway elicits autophagic cell death in Doxorubin-sensitive and resistant lung cancer. J Clin Med 7:321

Cho YJ, Park JP, Hwang HJ et al (2002) Production of red pigment by submerged culture of Paecilomyces sinclairii. Lett Appl Microbiol 35:195-202
Choi SY, Yoon KH, Lee JI, Mitchell RJ (2015) Violacein: properties and production of a versatile bacterial pigment. Biomed Res Int. https://doi.org/10.1155/2015/465056

Chyizhanska N, Beregova T (2009) Effect of melanin isolated from Antarctic yeasts on preservation of pig livestock after ablactation. Український антарктичний журнал.

Collins T, Gerday C (2017) Enzyme catalysis in psychrophiles. In: Margesin R (ed) Psychrophiles: from biodiversity to biotechnology, 2nd edn. Springer, Cham, pp 209-235

Collins T, Margesin R (2019) Psychrophilic lifestyles: mechanisms of adaptation and biotechnological tools. Appl Microbiol Biotechnol 103(7):2857-2871

Contreras G, Barahona S, Sepúlveda D et al (2015) Identification and analysis of metabolite production with biotechnological potential in Xanthophyllomyces dendrorhous isolates. World J Microbiol Biotechnol 31(3):517-526

Correa-Llantén DN, Amenabar MJ, Blamey JM (2012) Antioxidant capacity of novel pigments from an Antarctic bacterium. J Microbiol 50:374-379

Corsaro MM, Casillo A, Parrilli E, Tutino ML (2017) Molecular structure of lipopolysaccharides of cold-adapted bacteria. In: Margesin R (ed) Psychrophiles: from biodiversity to biotechnology, 2nd edn. Springer, Cham, pp 285-303

Cristea D, Vilarem G (2006) Improving light fastness of natural dyes on cotton yarn. Dyes Pigm 70(3):238-245

Cude WN, Mooney J, Tavanaei AA et al (2012) Production of the antimicrobial secondary metabolite indigoidine contributes to competitive surface colonization by the marine roseobacter Phaeobacter sp. strain Y4I. Appl Environ Microbiol 78(14):4771-4780

D'Amico S, Gerday C, Feller G (2001) Structural determinants of cold adaptation and stability in a large protein. J Biol Chem 276(28):25791-25796

D’Amico S, Collins T, Marx JC et al (2006) Psychrophilic microorganisms: challenges for life. EMBO Rep 7(4):385-389

Danevčič T, Borić Vezjak M, Tabor M et al (2016) Prodigiosin induces autolysis in actively grown Bacillus subtilis cells. Front Microbiol 7:27

Day PA, Villalba MS, Herrero OM et al (2017) Formation of indigoidine derived-pigments contributes to the adaptation of Vogesella sp. strain EB to cold aquatic iron-oxidizing environments. Antonie Van Leeuwenhoek 110(3):415-428

De Carvalho JC, Cardoso LC, Ghiggi V, Woiciechowski AL, de Souza Vandenberghe LP, Soccol CR (2014) Microbial Pigments. In: Brar S, Dhillon G, Soccol C (eds) Biotransformation of Waste Biomass into High Value Biochemicals. Springer, New York, NY, USA, pp 73-98

De Maayer P, Anderson D, Cary C, Cowan DA (2014) Some like it cold: understanding the survival strategies of psychrophiles. EMBO Rep 15(5):508-517

de Menezes GC, Godinho VM, Porto BA et al (2017) Antarctomyces pellizariae sp. nov., a new, endemic, blue, snow resident psychrophilic ascomycete fungus from Antarctica. Extremophiles 21:259-269

Deming JW, Young JN (2017) The role of exopolysaccharides in microbial adaptation to cold habitats. In: Margesin R (ed) Psychrophiles: from biodiversity to biotechnology, 2nd edn. Springer, Cham, pp 259-284

Dharmaraj S, Ashokkumar B, Dhevendaran K (2009) Food-gradepigments from Streptomyces sp. isolated from the marine sponge Callyspongia diffusa. Food Res Int 42:487-492. https://doi. org/10.1016/j.foodres.2009.02.006

Dieser M, Greenwood M, Foreman CM (2010) Carotenoid pigmentation in Antarctic heterotrophic bacteria as a strategy to withstand environmental stresses. Arct Antarct Alp Res 42(4):396-405 
Dillon JG, Castenholz RW (1999) Scytonemin, a cyanobacterial sheath pigment, protects against UVC radiation: implications for early photosynthetic life. J Phycol 35(4):673-681

Dimitrova S, Pavlova K, Lukanov L, Zagorchev P (2010) Synthesis of coenzyme $\mathrm{q} 10$ and $\beta$-carotene by yeasts isolated from Antarctic soil and lichen in response to ultraviolet and visible radiations. Appl Biochem Biotechnol 162:795-804

Dimitrova S, Pavlova K, Lukanov L et al (2013) Production of metabolites with antioxidant and emulsifying properties by Antarctic strain Sporobolomyces salmonicolor AL1. Appl Biochem Biotechnol 169:301-311

Domröse A, Weihmann R, Thies S et al (2017) Rapid generation of recombinant Pseudomonas putida secondary metabolite producers using yTREX. Synth Syst Biotechnol 2(4):310-319

Downham A, Collins P (2000) Colouring our foods in the last and next millennium. Int J Food Sci Tech 35:5-22

Dsouza M, Taylor MW, Turner SJ, Aislabie J (2015) Genomic and phenotypic insights into the ecology of Arthrobacter from Antarctic soils. BMC Genomics 16(1):36

Dufossé L (2016) Current and potential natural pigments from microorganisms (bacteria, yeasts, fungi, microalgae). In: Carle R, Schweiggert RM (eds) Handbook on natural pigments in food and beverages. Elsevier Ltd, Cambridge, pp 337-354

Dufosse L (2018) Microbial pigments from bacteria, yeasts, fungi, and microalgae for the food and feed industries. Natural and artificial flavoring agents and food dyes. Academic Press, USA, pp 113-132

Durán N, Erazo S, Campos V (1953) Bacterial chemistry-II: antimicrobial photoproduct from pigment of Chromobacterium violaceum. An Acad Bras Cienc 55:231-234

Duran N, Melo PS, Haun M (1996) In Vitro evaluation of violacein on AIDS-related lumphoma and human tumor cell lines. In: Proceedings of the 25th Annual Meetings of the Brazilian Society of Biochemistry and Molecular Biology, Sociedade Brasi-leira de Bioquimica e Biologia Molecular (SBBq), Caxambu, Brazil

Duran N, Justo GZ, Ferreira CV et al (2007) Violacein: properties and biological activities. Biotechnol Appl Biochem 48:127-133. https://doi.org/10.1042/BA20070115

Egorova AS, Gessler NN, Belozerskaya TA (2011) Melanin pigments in the fungus Paecilomyces lilacinus (thom) samson. Dokl Biochem Biophys 437(1):84

El-Naggar NE, El-Ewasy SM (2017) Bioproduction, characterization, anticancer and antioxidant activities of extracellular melanin pigment produced by newly isolated microbial cell factories Streptomyces glaucescens NEAE-H. Sci Rep 14:42129. https://doi. org/10.1038/srep42129

Ewert M, Deming JW (2013) Sea ice microorganisms: environmental constraints and extracellular responses. Biology 2(2):603-628. https://doi.org/10.3390/biology2020603

Feofilova EP, Tereshina VM, Gorova IB (1994) Changes in carbohydrate composition of fungi during adaptation to thermostress. Microbiology 63:442-445

Ferreira CV, Bos CL, Versteeg HH et al (2004) Molecular mechanism of violacein-mediated human leukemia cell death. Blood 104:14464-14591

Fleming ED, Castenholz RW (2007) Effects of periodic desiccation on the synthesis of the UV-screening compound, scytonemin, in cyanobacteria. Environ Microbiol 9(6):1448-1455

Foght J, Aislabie J, Turner S et al (2004) Culturable bacteria in subglacial sediments and ice from two southern hemisphere glaciers. Microb Ecol 47(4):329-340

Fong NJC, Burgess ML, Barrow KD, Glenn DR (2001) Carotenoid accumulation in the psychrotrophic bacterium Arthrobacter agilis in response to thermal and salt stress. Appl Microbiol Biotechnol 56:750-756. https://doi.org/10.1007/s002530100739
Foo J, Michor F (2014) Evolution of acquired resistance to anti-cancer therapy. J Theor Biol 355:10-20

Fouillaud M, Venkatachalam M, Girard-Valenciennes E et al (2016) Anthraquinones and derivatives from marine-derived fungi: structural diversity and selected biological activities. Mar Drugs 14:64

Frank S, Schmidt F, Klockgether J et al (2011) Functional genomics of the initial phase of cold adaptation of Pseudomonas putida KT2440. FEMS Microbiol Lett 318:47-54

Fraser PD, Bramley PM (2004) The biosynthesis and nutritional uses of carotenoids. Prog Lipid Res 43(3):228-265

Fukuda W, Kimura T, Araki S et al (2013) Lysobacteroligotrophicus sp. Nov., isolated from an Antarctic freshwater lake in Antarctica. Int J Syst Evol Microbiol 63(9):3313-3318

Füller JJ, Röpke R, Krausze J et al (2016) Biosynthesis of violacein, structure and function of 1-Tryptophan oxidase VioA from Chromobacterium violaceum. J Biol Chem 291(38):20068-20084

Gerber NN (1975) Prodigiosin-like pigments. CRC Crit Rev Microbiol 3:469-485. https://doi.org/10.3109/10408417509108758

Gessler NN, Egorova AS, Belozerskaya TA (2013) Fungal anthraquinones. Appl Biochem Microbiol 49:85-99

Gessler NN, Egorova AS, Belozerskaya TA (2014) Melanin pigments of fungi under extreme environmental conditions. Appl Biochem Micro 50(2): 105-113

Ghobakhlou AF, Johnston A, Harris L et al (2015) Microarray transcriptional profiling of Arctic Mesorhizobium strain N33 at low temperature provides insights into cold adaption strategies. BMC Genomics 16(1):383. https://doi.org/10.1186/s12864015-1611-4

Ghosh A, Goyal A, Jain RK (2007) Study of methanol-induced phenotypic changes in a novel strain of Acinetobacter lwoffii. Arch Microbiol 188:533-539

Gmoser R, Ferreira JA, Lennartsson PR, Taherzadeh MJ (2017) Filamentous ascomycetes fungi as a source of natural pigments. Fungal Biol Biotechnol 4(1):4

González-Toril E, Amils R, Delmas RJ et al (2008) Diversity of bacteria producing pigmented colonies in aerosol, snow and soil samples from remote glacial areas (Antarctica, Alps and Andes). Biogeosci Discuss 5:1607-1630

Goordial J, Raymond-Bouchard I, Zolotarov Y et al (2016) Cold adaptive traits revealed by comparative genomic analysis of the eurypsychrophile Rhodococcus sp. JG3 isolated from high elevation McMurdo Dry Valley permafrost, Antartica. FEMS Microbiol Ecol. https://doi.org/10.1093/femsec/fiv154

Gorbushina A (2003) Methodologies and techniques for detecting extraterrestrial (microbial) life microcolonial fungi: survival potential of terrestrial vegetative structures. Astrobiology 3:543-554

Gounot AM (1991) Bacterial life at low temperature: physiological aspects and biotechnological implications. J Appl Bacteriol 71:386-397

Gromek SM, Suria AM, Fullmer MS et al (2016) Leisingera sp JC1, a bacterial isolate from Hawaiian bobtail squid eggs, produces indigoidine and differentially inhibits vibrios. Front Microbiol $7: 1342$

Gu JD, Cheung KH (2001) Phenotypic expression of Vogesella indigofera upon exposure to hexavalent chromium, Cr6+. World J Microb Biot 17:475-480

Gunasekaran S, Poorniammal R (2008) Optimization of fermentation conditions for red pigment production from Penicillium sp. under submerged cultivation. Afr J Biotechnol 7:1894-1898

Gupta S, Aggarwal S (2014) Novel bio-colorants for textile application from fungi. J Textile Assoc 74:282-287

Haddix PL, Jones S, Patel P et al (2008) Kinetic analysis of growth rate, ATP, and pigmentation suggests an energy-spilling function for the pigment prodigiosin of Serratia marcescens. J Bacteriol 190(22):7453-7463 
Hajjaj H, Blanc P, Groussac E et al (2000) Kinetic analysis of red pigment and citrinin by Monascus rubber as a function of organic acid accumulation. Enzym Microb Technol 27:619-625

Hakvag S, Fjaervik E, Klinkenberg G et al (2009) Violacein-producing Collimonas sp. from the sea surface microlayer of costal waters in Trondelag, Norway. Mar Drugs 7:576-588. https://doi. org $/ 10.3390 / \mathrm{md} 7040576$

Harris AK, Williamson NR, Slater H et al (2004) The Serratia gene cluster encoding biosynthesis of the red antibiotic, prodigiosin, shows species and strain-dependent genome context variation. Microbiology 150:3547-3560. https://doi.org/10.1099/ mic. $0.27222-0$

Hasan N, Hasan F, Nadeem S et al (2018) Community analysis and characterization of fungi from Batura glacier, Karakoram mountain range, Pakistan. Appl Ecol Environ Res 16(5):5323-5341

Hassan N, Anesio AM, Rafiq M et al (2020) Cell membrane fatty acid and pigment composition of the psychrotolerant cyanobacterium Nodularia spumigena CHS1 isolated from Hopar glacier, Pakistan. Extremophiles 24(1):135-145

He J, Yang Z, Hu B et al (2015) Correlation of polyunsaturated fatty acids with the cold adaptation of Rhodotorula glutinis. Yeast 32(11):683-690. https://doi.org/10.1002/yea.3095

Heider SA, Peters-Wendisch P, Wendisch VF (2012) Carotenoid biosynthesis and overproduction in Corynebacterium glutamicum. BMC Microbiol 12(1):198

Ho TF, Peng YT, Chuang SM et al (2009) Prodigiosin down-regulates survivin to facilitate paclitaxel sensitization in human breast carcinoma cell lines. Toxicol Appl Pharm 235:253-260

Hood DW, Heidstra R, Swoboda UK, Hodgson DA (1992) Molecular genetic analysis of proline and tryptophan biosynthesis in Streptomyces coelicolor A3(2): interaction between primary and secondary metabolism - a review. Gene 115:5-12

Huang HC, Chiu SH, Ke HJ et al (2011) Antimelanogenic and antioxidant activities of Bifidobacterium infantis. Afr J Microbiol Res 5:3150-3156

Huang JP, Mojib N, Goli RR et al (2012) Antimicrobial activity of PVP from an Antarctic bacterium, Janthinobacterium sp. Ant5-2, on multi-drug and methicillin resistant Staphylococcus aureus. Nat Products Bioprospect 2(3):104-110

Hughes KA, Lawley B, Newsham KK (2003) Solar UV-B radiation inhibits the growth of Antarctic terrestrial fungi. Appl Environ Microbiol 69:1488-1491

Hughes KA, Cowan DA, Wilmotte A (2015) Protection of Antarctic microbial communities- 'out of sight, out of mind'. Front Microbiol 6:151. https://doi.org/10.3389/fmicb.2015.00151

Ibarrondo I, Prieto-Taboada N, Martínez-Arkarazo I, Madariaga JM (2016) Resonance Raman imaging as a tool to assess the atmospheric pollution level: carotenoids in Lecanoraceae lichens as bioindicators. Environ Sci Pollut 23(7):6390-6399

Ibrahim A (2008) Production of carotenoids by a newly isolated marine Micrococcus sp. Biotechnology 7:469-474

Jabour J (2010) Biological prospecting: the ethics of exclusive reward from Antarctic activity. Ethics Sci Environ Polit 10:19-29

Joshi VK, Attri D, Bala A, Bhushan S (2003) Microbial pigments. Indian J Biotechnol 2:362-369

Kamla M, Jayanti T, Sneh G (2012) A review on microbial pigment. Int J Microbial Res Technol 1(4):361-365

Kennicutt MC, Chown SL, Cassano JJ et al (2014) Polar research: six priorities for Antarctic science. Nature 512(7512):23-25

Kim SK (2013) Marine biomaterials: characterization, isolation and applications. CRC Press/Taylor \& Francis, Boca Raton

Kim SJ, Shin SC, Hong SG, Lee YM, Lee H, Lee J, Choi IG, Park $\mathrm{H}$ (2012) Genome sequence of Janthinobacterium sp. strain PAMC 25724, isolated from alpine glacier cryoconite. J Bacteriol 194(8):2096-2096
Kim JH, Kang HJ, Yu BJ et al (2015) Planococcus faecalis sp. Nov., a carotenoid-producing species isolated from stools of Antarctic penguins. Int J Syst Evol Microbiol 65(10):3373-3378

Kimura T, Fukuda W, Sanada T, Imanaka T (2015) Characterization of water-soluble dark-brown pigment from Antarctic bacterium, Lysobacter oligotrophicus. J Biosci Bioeng 120(1):58-61

Kitamoto D, Yanagishita H, Endo A et al (2001) Remarkable antiagglomeration effect of a yeast biosurfactant, diacylmannosylerythritol, on ice-water slurry forcold thermal storage. Biotechnol Prog 17(2):362-365. https://doi.org/10.1021/bp000159f

Kobayashi H, Nogi Y, Horikoshi K (2007) New violet 3, 3'-bipyridyl pigment purified from deep-sea microorganism Shewanella violacea DSS12. Extremophiles 11(2):245-250

Kodach LL, Bos CL, Durán N et al (2017) Violacein synergistically increases 5-fluoro-uracil cytotoxicity, induces apoptosis and inhibits Akt-mediated signal transduction in human colorectal cancer cells. Carcinogenesis 27:508-516

Konuray G, Erginkaya Z (2015) Antimicrobial and antioxidant properties of pigments synthesized from microorganisms. In: Méndez-Vilas A (ed) The battle against microbial pathogens: basic science, technological advances and educational programs. Formatex Research Center, Spain, pp 27-33

Koyama J (2006) Anti-infective quinone derivatives of recent patents. Recent Pat Anti-Infect Drug Discov 1:113-125

Kramar A, Llic Tomic T, Petkovic M et al (2014) Crude bacterial extracts of two new Streptomyces sp. isolates as bio-colorants for textile dyeing. World J Microbiol Biotechnol 30:2231-2240. https://doi.org/10.1007/s11274-014-1644-x

Krishna JG (2008) Pigment production by marine Serratia sp. BTW J8. Doctoral dissertation, Ph. D. Thesis. Department of Biotechnology, Cochin University of Science and Technology, Cochin, Kerala, India

Kushwaha K, Saxena J, Tripathi BK, Agarwal MK (2014) Detection of carotenoids in psychrotrophic bacteria by spectroscopic approach. J BioSci Biotechnol 3(3):253-260

Leiva S, Alvarado P, Huang Y, Wang J, Garrido I (2015) Diversity of pigmented Gram-positive bacteria associated with marine macroalgae from Antarctica. FEMS Microbiol Lett 362(24):fnv206

Li F, Xue F, Yu X (2017) GC-MS, FTIR and Raman analysis of antioxidant components of red pigments from Stemphylium lycopersici. Curr Microbiol 74:532-539. https://doi.org/10.1007/s0028 4-017-1220-3

Liao L, Liu C, Zeng Y, Zhao B, Zhang J, Chen B (2019) Multipartite genomes and the sRNome in response to temperature stress of an Arctic Pseudoalteromonas fuliginea BSW20308. Environ Microbiol 21(1):272-285

Lim J, Thomas T, Cavicchioli R (2000) Low temperature regulated DEAD-box RNA helicase from the Antarctic archaeon Methanococcoides burtonii. J Mol Biol 297(3):553-567

Lin SR, Weng CF (2018) PG-priming enhances doxorubin influx to trigger necrotic and autophagic cell death in oral squamous cell carcinoma. J Clin Med 7:375

Liu Q, Liu HC, Zhou YG, Xin YH (2019) Microevolution and adaptive strategy of psychrophilic species Flavobacterium bomense sp. Nov. isolated from glaciers. Front Microbiol 10:1069

Lobo V, Patil A, Phatak A, Chandra N (2010) Free radicals, antioxidants and functional foods: impact on human health. Pharmacogn Rev 4:118-126

Lorv JS, Rose DR, Glick BR (2014) Bacterial ice crystal controlling proteins. Scientifica. https://doi.org/10.1155/2014/976895

Lu Y, Wang L, Xue Y et al (2009) Production of violet pigment by a newly isolated psychrotrophic bacterium from a glacier in Xinjiang, China. Biochem Eng J 43(2): 135-141

Madigan MT, Martinko JM, Stahl DA, Clark DP (2012) Brock biology of microorganisms, 13th edn. Pearson Education, Inc, San Francisco 
Mageswari A, Subramanian P, Srinivasan R et al (2015) Astaxanthin from psychrotrophic Sphingomonas faeni exhibits antagonism against food-spoilage bacteria at low temperatures. Microbiol Res 179:38-44

Maheswarappa G, Kavitha D, Vijayarani K, Kumanan K (2013) Prodigiosin as anticancer drug produced from bacteria of termite gut. Indian J Basic Appl Med Res 3:257-266

Manikprabhu D, Lingappa K (2013) Actinorhodin a natural and attorney source for synthetic dye to detect acid production of fungi. Saudi J Biol Sci 20:163-168. https://doi.org/10.1016/j. sjbs.2013.01.004

Margalith PZ (1992) Pigment microbiology. Chapman \& Hall, London, pp 1-156

Margesin R, Collins T (2019) Microbial ecology of the cryosphere (glacial and permafrost habitats): current knowledge. Appl Microbiol Biotechnol. https://doi.org/10.1007/s00253-019-09631-3

Margesin R, Schumann P, Spröer C, Gounot AM (2004) Arthrobacter psychrophenolicus sp. Nov., isolated from an alpine ice cave. Int J Syst Evol Microbiol 54(6):2067-2072

Marizcurrena JJ, Morel MA, Braña V et al (2017) Searching for novel photolyases in UVC-resistant Antarctic bacteria. Extremophiles 21(2):409-418

Marizcurrena JJ, Cerdá MF, Alem D, Castro-Sowinski S (2019) Living with pigments: the colour palette of Antarctic life. The ecological role of micro-organisms in the Antarctic environment. Springer, Cham, pp 65-82

Martin-Cerezo ML, Garcia-Lopez E, Cid C (2015) Isolation and identification of a red pigment from the Antarctic bacterium Shewanella frigidimarina. Protein Peptide Lett 22:1076-1082

Medentsev AG, Arinbasarova AY, Akimenko VK (2005) Biosynthesis of naphthoquinone pigments by fungi of the genus Fusarium. Appl Biochem Microbiol 41:503-5076

Medigue C, Krin E, Pascal G et al (2005) Coping with cold: the genome of the versatile marine Antarctica bacterium Pseudoalteromonas haloplanktis TAC125. Genome Res 15(10):1325-1335

Melo PS, Justo GZ, de Azevedo MB, Duran N, Haun M (2003) Violacein and its beta-cyclodextrin complexes induce apoptosis and differentiation in HL60 cells. Toxicology 186:217-225

Melo PS, Maria SS, de Campos VB, Haun M, Durán N (2000) Violacein cytotoxicity and induction of apoptosis in V79 cells. In Vitro Cell Dev-Biol 36:5343-5395

Mojib N, Philpott R, Huang JP, Niederweis M, Bej AK (2010) Antimycobacterial activity in vitro of pigment isolated from Antartica bacteria. Anton Van Leeuwen 98:531-540

Mojib N, Farhoomand A, Anderson DT, Bej AK (2013) UV and cold tolerance of a pigment- producing Antarctic Janthinobacterium sp. Ant5-2. Extremophiles 17:367-378

Moliné M, Libkind D, Dieguez MC, van Broock M (2009) Photoprotective role of carotenoid pigments in yeasts: experimental study contrasting naturally occurring pigmented and albino strains. J Photochem Photobiol B 95:156-161

Montagni T, Enciso P, Marizcurrena JJ et al (2018) Dye sensitized solar cells based on Antarctic Hymenobacter sp. UV11 dyes. J. Environ Sustain 1(1):89-97

Mueller DR, Vincent WF, Bonilla S, Laurion I (2005) Extremotrophs, extremophiles and broadband pigmentation strategies in a high arctic ice shelf ecosystem. FEMS Microbiol Ecol 53(1):73-87. https://doi.org/10.1016/j.femsec.2004.11.001

Mykytczuk NCS, Foote SJ, Omelon CR, Southam G, Greer CW, Whyte LG (2013) Bacterial growth at $-15^{\circ} \mathrm{C}$; molecular insights from the permafrost bacterium Planococcus halocryophilus Or1. ISME J 7:1211-1226. https://doi.org/10.1038/ismej.2013.8

Nakamura Y, Sawada T, Morita Y et al (2002) Isolation of a psychrotrophic bacterium from the organic residue of a water tank keeping rainbow trout and antibacterial effect of violet pigment produced from the strain. Biochem Eng J 12(1):79-86

Namazkar S, Ahmad WA (2013) Spray-dried prodigiosin from Serratia marcescens as a colorant. Biosci Biotech Res Asia 10(1):69-76

Nelis HJ, De Leenheer AP (1991) Microbial sources of carotenoid pigments used in foods and feeds. J Appl Bacteriol 70(3):181-191

Nigam PS, Luke JS (2016) Food additives: production of microbial pigments and their antioxidant properties. Curr Opin Food Sci 7:93-100

Nwankwo IU, Itaman VO, Chidiebere OL, Nwachukwu MP (2017) Evaluation of antimicrobial activity of prodigiosin produced from Serratia marcescens against some pathogenic bacteria. Futo J Ser 3:93-102

Ogugbue CJ, Sawidis T (2011) Bioremediation and detoxification of synthetic waste water containing triarylmethane dyes by Aeromonas hydrophila isolated from industrial effluent. Biotechnol Res Int. https://doi.org/10.4061/2011/967925

Okuyama H, Orikasa Y, Nishida T (2008) Significance of antioxidative functions of eicosapentaenoic and docosahexaenoic acids in marine microorganisms. Appl Environ Microbiol 74(3):570-574

Omamor IB, Eziashi EI, Adekunle AA (2008) Carbon nutrition in relation to growth of three Monascus species isolated from decaying date fruits. Afr J Microbiol Res 2:153-155

Onofri S, Selbmann L, Zucconi L, Pagano S (2004) Antarctic microfungi as models for exobiology. Planet Space Sci 52:229-237

Órdenes-Aenishanslins N, Anziani-Ostuni G, Vargas-Reyes M et al (2016) Pigments from UV-resistant Antarctic bacteria as photosensitizers in dye sensitized solar cells. J Photochem Photobiol B 162:707-714

Osawa A, Ishii Y, Sasamura N et al (2010) Characterization and antioxidative activities of rare C50 carotenoids-sarcinaxanthin, sarcinaxanthin monoglucoside, and sarcinaxanthin diglucoside obtained from Micrococcus yunnanensis. J Oleo Sci 59:653-659

Pagano MC, Dhar PP (2015) Fungal pigments: an overview. In: Gupta VK, Mach RL, Sreenivasaprasad S (eds) Fungal biomolecules: sources, applications and recent developments. $1^{\text {st }}$ edn., Wiley, London. ISBN: 978-1-118-95829-2

Pandey N, Rahul J, Anita P, Sushma T (2018) Optimisation and characterisation of the orange pigment produced by a cold adapted strain of Penicillium sp. (GBPI_P155) isolated from mountain ecosystem. Mycology 9(2):81-92. https://doi.org/10.1080/21501 203.2017.1423127

Pantanella F, Berlutti F, Passariello C et al (2007) Violacein and biofilm production in Janthinobacterium lividum. J Appl Microbiol 102(4):992-999

Panwar AS, Molpa D, Joshi GK (2019) Biotechnological potential of some cold-adapted bacteria isolated from North-Western Himalaya. Microbiology 88(3):343-352

Parmar M, Phutela UG (2015) Biocolors: the new generation additives. Int J Curr Microbiol Appl Sci 4(7):688-694

Parmar TK, Rawtani D, Agrawal YK (2016) Bioindicators: the natural indicator of environmental pollution. Front Life Sci 9(2):110-118

Perfumo A, Banat IM, Marchant R (2018) Going green and cold: biosurfactants from low-temperature environments to biotechnology applications. Trends Biotechnol 36(3):277-289. https://doi. org/10.1016/j.tibtech.2017.10.016

Pezzella A, Gargiulo V, Alfè M et al (2019) Eumelanin graphenelike integration: the impact on physical properties and electrical conductivity. Front Chem 7:121. https://doi.org/10.3389/fchem 2019.00121

Phaniendra A, Jestadi DB, Periyasamy L (2015) Free radicals; properties, sources, targets, and their implication in various diseases. Indian J Clin Biochem 30:11-26

Piette F, D'Amico S, Mazzucchelli G et al (2011) Life in the cold: a proteomic study of cold-repressed proteins in the Antarctic 
bacterium Pseudoalteromonas haloplanktis TAC125. Appl Environ Microbiol 77(11):3881-3883. https://doi.org/10.1128/ aem.02757-10

Poorniammal R, Parthiban M, Gunasekaran S et al (2013) Natural dye production from Thermomyces sp. fungi for textile application. Indian J Fiber Textile Res 38:276-279

Potera C (2010) Diet and nutrition: the artificial food dye blues. Environ Health Perspect 118(10):A428-A428

Prabhu S, Rekha PD, Young CC et al (2013) Zeaxanthin production by novel marine isolates from coastal sand of India and its antioxidant properties. Appl Biochem Biotech 171:817-831

Pradeep FS, Pradeep BV (2013) Optimization of pigment and biomass production from Fusarium moniliforme under submerged fermentation conditions. Int J Pharm Pharm Sci 5:526-535

Prashanthi K, Suryan S, Varalakshmi KN (2015) In vitro anticancer property of yellow pigment from Streptomyces griseoaurantiacus JUACT 01. Braz Arch Biol Technol 58:869-876

Puig-Marcó R (2014) Access and benefit sharing of Antarctica's biological material. Mar Genomics 17:73-78. https://doi. org/10.1016/j.margen.2014.04.008

Rafiq M, Hayat M, Anesio AM et al (2017) Recovery of metallo-tolerant and antibiotic resistant psychrophilic bacteria from Siachen glacier, Pakistan. PloS one 12(7):e0178180

Rafiq M, Hayat M, Zada S et al (2019) Geochemistry and bacterial recovery from Hindu Kush Range glacier and their potential for metal resistance and antibiotic production. Geomicrobiology $\mathbf{J}$ 36(4):326-338

Rai M (2009) Advances in fungal biotechnology. I. K. International Pvt Ltd., New Delhi, p 545

Ramesh C, Vinithkumar NV, Kirubagaran R et al (2019) Multifaceted applications of microbial pigments: current knowledge, challenges and future directions for public health implications. Microorganisms 7(7):186

Rao AV, Rao LG (2007) Carotenoids and human health. Pharmacol Res 55(3):207-216

Rao N, Prabhu M, Xiao M, Li WJ (2017) Fungal and bacterial pigments: secondary metabolites with wide applications. Front Microbiol 8:1113

Ravikumar S, Uma G, Gokulakrishnan R (2016) Antibacterial property of Halobacterial carotenoids against human bacterial pathogens. J Sci Ind (India) 75:253-257

Raymond JA, Christner BC, Schuster SC (2008) A bacterial ice-binding protein from the Vostok ice core. Extremophiles 12(5):713-717. https://doi.org/10.1007/s00792-008-0178-2

Reddy GS, Prakash JS, Prabahar V et al (2003) Kocuria polaris sp nov, an orange-pigmented psychrophilic bacterium isolated from an Antarctic cyanobacterial mat sample. Int J Syst Evol Microbiol 53(1):183-187

Reichenbach H, Kleinig H, Achenbach H (1974) The pigments of Flexibacter elegans: novel and chemosystematically useful compounds. Arch Microbiol 101:131-144

Reverchon S, Rouanet C, Expert D, Nasser W (2002) Characterization of indigoidine biosynthetic genes in Erwinia chrysanthemi and role of this blue pigment in pathogenicity. J Bacteriol 184(3):654-665

Rezaeeyan Z, Safarpour A, Amoozegar MA et al (2017) High carotenoids production by a halotolerant bacterium, Kocuria sp. strain QWT-12 and anticancer activity of its carotenoids. EXCLI J $16: 840-851$

Robinson CH (2001) Cold adaptation in Arctic and Antarctic fungi. New Phytol 151(2):341-353

Robledo JA, Murillo AM, Rouzaud F (2011) Physiological role and potential clinical interest of mycobacterial pigments. IUBMB Life 63:71-78
Roos JC, Vincent WF (1998) Temperature dependence of UV radiation effects on Antarctic cyanobacteria. J Phycol 34:118-125

Rosa LH, Vaz AB, Caligiorne RB, Campolina S, Rosa CA (2009) Endophytic fungi associated with the Antarctic grass Deschampsia antarctica Desv. (Poaceae). Polar Biol 32(2):161-167

Ryazantseva IN, Andreyeva IN, Klementyeva GS et al (1995) Pigment-dependent light influence on the energetics of Serratia marcescens. Thermochim Acta 251:63-67

Sabbe K, Hodgson DA, Verleyen E et al (2004) Salinity, depth and the structure and composition of microbial mats in continental Antarctic lakes. Freshw Biol 49(3):296-319

Sajjad W, Ahmad M, Khan S et al (2017) Radio-protective and antioxidative activities of astaxanthin from newly isolated radioresistant bacterium Deinococcus sp. strain WMA-LM9. Ann Microbiol 67(7):443-455

Santiago M, Ramírez-Sarmiento CA, Zamora RA, Parra LP (2016) Discovery, molecular mechanisms, and industrial applications of cold-active enzymes. Front Microbiol 7(1408). https://doi. org/10.3389/fmicb.2016.01408

Saviola B (2014) Pigments and pathogenesis. J Mycobact Dis 4:1068-2161

Schindler PR, Metz H (1989) Bacteria of the Flexibacter/Sporocytophaga group and violet-pigmented bacteria as indicators for hygienically doubtful drinking water. Zentralblatt fur Hygiene und Umweltmedizin. Int J Hyg Envir Med 189(1):29-36

Schloss PD, Allen HK, Klimowicz AK et al (2010) Psychrotrophic strain of Janthinobacterium lividum from a cold Alaskan soil produces prodigiosin. DNA Cell Biol 29(9):533-541

Schneemann I, Wiese J, Kunz AL, Imhoff JF (2011) Genetic approach for the fast discovery of phenazine producing bacteria. Mar Drugs 9:772-789

Seganish JL, Davis JT (2005) Prodigiosin is a chloride carrier that can function as an anion exchanger. Chem Commun 46:5781-5783

Segawa T, Yoshimura Y, Watanabe K et al (2011) Community structure of culturable bacteria on surface of Gulkana Glacier. Alaska Polar Sci 5(1):41-51

Selbmann L, Zucconi L, Isola D, Onofri S (2015) Rock black fungi: excellence in the extremes, from the Antarctic to space. Curr Genet 61:335-345

Selvameenal L, Radhakrishnan M, Balagurunathan R (2009) Antibiotic pigment from desert soil actinomycetes; biological activity, purification and chemical screening. Indian J Pharm Sci 71:499-504. https://doi.org/10.4103/0250-474X.58174

Shen L, Liu Y, Wang N et al (2018) Variation with depth of the abundance, diversity and pigmentation of culturable bacteria in a deep ice core from the Yuzhufeng Glacier, Tibetan Plateau. Extremophiles 22(1):29-38. https://doi.org/10.1007/ s00792-0170973-8

Shindo K, Misawa N (2014) New and rare carotenoids isolated from marine bacteria and their antioxidant activities. Mar Drugs 12:1690-1698

Shirata A, Tsukamoto T, Yasui H et al (1997) Production of bluish-purple pigments by Janthinobacterium lividum isolated from the raw silk and dyeing with them. Nihon Sanshigaku Zasshi 66:377-385

Shirata A, Tsukamoto T, Yasui H et al (2000) Isolation of bacteria producing bluish-purple pigment and use for dyeing. Jpn Agric Res Q 34:131-140

Shivaji S, Ray MK, Kumar GS et al (1991) Identification of Janthinobacterium lividum from the soils of the islands of Scotia Ridge and from Antarctic peninsula. Polar Biol 11(4):267-271

Siddiqui KS, Williams TJ, Wilkins D et al (2013) Psychrophiles. Annu Rev Earth Planet Sci 41:87-115 
Siefirmann-Harms D (1987) The light-harvesting and protective functions of carotenoids in photosynthetic membranes. Physiol Plant 69:501-568

Sikkandar S, Murugan K, Al-Sohaibani S et al (2013) Halophilic bacteria-a potent source of carotenoids with antioxidant and anticancer potentials. J Pure Appl Microbiol 7:2825-2830

Silva TR, Tavares RS, Canela-Garayoa R et al (2019) Chemical characterization and biotechnological applicability of pigments isolated from Antarctic bacteria. Mar Biotechnol 21(3):416-429

Singgih M, Andriatna W, Damayanti S, Priatni S (2015) Carotenogenesis study of Neurospora intermedia $\mathrm{N}-1$ in liquid. J Chem Pharm Res 7:842-847

Singh AK, Sad K, Singh SK, Shivaji S (2014) Regulation of gene expression at low temperature: role of cold-inducible promoters. Microbiology 160(7):1291-1296. https://doi.org/10.1099/ mic.0.077594-0

Singh A, Krishnan KP, Prabaharan D, Sinha RK (2017) Lipid membrane modulation and pigmentation: a cryoprotection mechanism in Arctic pigmented bacteria. J Basic Microbiol 57(9):770-780

Sinha RP, Klisch M, Gröniger A, Häder DP (1998) Ultraviolet-absorbing/screening substances in cyanobacteria, phytoplankton and macroalgae. J Photochem Photobiol B 47(2-3):83-94

Sivaperumal P, Kamala K, Rajaram R (2015) Bioactive DOPA melanin isolated and characterized from a marine actinobacterium Streptomyces sp. MVCS6 from Versova coast. Nat Prod Res 29:2117-2121

Smith D, da Silva M, Jackson J, Lyal C (2017) Explanation of the Nagoya Protocol on access and benefit sharing and its implication for microbiology. Microbiology 163(3):289-296

Solano F (2014) Melanin: skin pigments and much more-types, structural models, biological functions, and formation routes. New $\mathbf{J}$ Sci 2014:1-28. https://doi.org/10.1155/2014/498276

Soliev AB, Hosokawa K, Enomoto K (2011) Bioactive pigments from marine bacteria: applications and physiological roles. Evid Based Complement Alternat Med. https://doi.org/10.1155/2011/670349

Sommaruga R, Libkind D, Broock M, Whitehead K (2004) Mycosporine-glutaminol-glucoside, a UV-absorbing compound of two Rhodotorula yeast species. Yeast 21:1077-1081

Stafsnes MH, Bruheim P (2013) Pigmented marine heterotrophic bacteria. In: Kim S (ed) Marine biomaterials: characterization, isolation and applications, CRC Press/Taylor \& Francis Group, London, pp 117-148

Stankovic N, Senerovic L, Ilic-Tomic T et al (2014) Properties and applications of undecylprodigiosin and other bacterial prodigiosins. Appl Microbiol Biotechnol 98:3841-3858

Starič N, Danevčič T, Stopar D (2010) Vibrio sp. DSM 14379 pigment production-a competitive advantage in the environment? Microb Ecol 60:592-598

Suba KP, Stalin A, Girija AS, Raguraman R (2013) Homology modelling and docking analysis of prodigiosin from Serratia marcescens. Biotechnology 55:12897-12902

Subramaniam S, Ravi V, Sivasubramanian A (2014) Synergistic antimicrobial profiling of violacein with commercial antibiotics against pathogenic micro-organisms. Pharm Biol 52:86-90

Suresh M, Renugadevi B, Brammavidhya S et al (2015) Antibacterial activity of red pigment produced by Halolactibacillus alkaliphilus MSRD1-an isolate from seaweed. Appl Biochem Biotech 176:185-195

Suryawanshi RK, Patil CD, Borase HP et al (2015) Towards an understanding of bacterial metabolites prodigiosin and violacein and their potential for use in commercial sunscreens. Int J Cosmet Sci 37(1):98-107

Suryawanshi RK, Patil CD, Koli SH, Hallsworth JE, Patil SV (2017) Antimicrobial activity of prodigiosin is attributable to plasmamembrane damage. Nat Prod Res 31:572-577
Sutthiwong N, Fouillaud M, Valla A et al (2014) Bacteria belonging to the extremely versatile genus Arthrobacter as novel source of natural pigments with extended hue range. Food Res Int 65:156-162

Tarangini K, Mishra S (2014) Production of melanin by soil microbial isolate on fruit waste extract: two step optimizations of key parameters. Biotechnol Rep 4:139-146

Tashirev AB, Romanovskaia VA, Shilin SO, Chernaia NA (2010) Screening of yeast-producers of melanin in the Antarctic terrestrial biotopes. Mikrobiol Zh 72:3-8

Thomson NR, Crow MA, McGowan SJ et al (2000) Biosynthesis of carbapenem antibiotic and prodigiosin pigment in Serratia is under quorum sensing control. Mol Microbiol 36:539-556

Tian B, Hua Y (2010) Carotenoid biosynthesis in extremophilic Deinococcus-Thermus bacteria. Trends Microbiol 18(11):512-520

Tribelli PM, Lopez NI (2018) Reporting key features in cold-adapted bacteria. Life (Basel). https://doi.org/10.3390/life8010008

Tribelli PM, Solar Venero EC, Ricardi MM et al (2015) Novel essential role of ethanol oxidation genes at low temperature revealed by transcriptome analysis in the Antarctic bacterium Pseudomonas extremaustralis. PLoS ONE 10(12):e0145353

Trochine A, Turchetti B, Vaz ABM et al (2017) Description of Dioszegia patagonica sp. nov., a novel carotenogenic yeast isolated from cold environments. Int J Syst Evol Microbiol 67:4332-4339

Tuli HS, Chaudhary P, Beniwal V, Sharma AK (2015) Microbial pigments as natural color sources: current trends and future perspectives. J Food Sci Technol 52:4669-4678. https://doi.org/10.1007/ s13197-014-1601-6

Turk M, Plemenitaš A, Gunde-Cimerman N (2011) Extremophilic yeasts: plasma-membrane fluidity as determinant of stress tolerance. Fungal Biol 115(10):950-958

Umadevi K, Krishnaveni M (2013) Antibacterial activity of pigment produced from Micrococcus luteus KF532949. Int J Chem Anal Sci 4:149-152. https://doi.org/10.1016/j.ijcas.2013.08.008

UNEP (2012) An update on biological prospecting in Antarctica and recent policy developments at the international level. ATCM XXXV Meeting. https://www.unep.org/dewa/Portals/67/pdf/ ATCM35_ip063_e.pdf

UNU UNEP (2009) Biological prospecting: an update on recent policy developments at the international level. ATCM XXXII meeting. https://www.unep.org/dewa/Portals/67/pdf/Atcm32_ip091_e.pdf

Van Duin D, Casadevall A, Nosanchuk JD (2002) Melanization of Cryptococcus neoformans and Histoplasma capsulatum reduces their susceptibilities to amphotericin B and caspofungin. Antimicrob Agents Chemother 46(11):3394-3400

Vasanthabharathi V, Lakshminarayanan R, Jayalakhshmi S (2011) Melanin production from marine Streptomyces. Afr J Biotechnol 10:11224-11234

Vasileva-Tonkova E, Romanovskaya V, Gladka G et al (2014) Ecophysiological properties of cultivable heterotrophic bacteria and yeasts dominating in phytocenoses of Galindez Island, Maritime Antarctica. World J Microbiol Biotechnol 30:1387-1398

Vaz AB, Rosa LH, Vieira ML et al (2011) The diversity, extracellular enzymatic activities and photoprotective compounds of yeasts isolated in Antarctica. Braz J Microbiol 42(3):937-947

Vendruscolo F, Pitol LO, Carciofi BAM et al (2010) Construction and application a vanesystem in a rotational rheometer for determination of the rheological properties of Monascus ruber CCT 3802. J Biorheol 24:29-35

Venil CK, Aruldass CA, Dufosse L et al (2014) Current perspective on bacterial pigments: emerging sustainable compounds with coloring and biological properties for the industry-an incisive evaluation. RSC Adv 4:39523-39529. https://doi.org/10.1039/ c4ra06162d

Venil CK, Zakaria ZA, Ahmad WA (2013) Bacterial pigments and their applications. Process Biochem 48:1065-1079. https://doi. org/10.1016/j.procbio.2013.06.006 
Venil CK, Yusof NZ, Aruldass CA et al (2016) Application of violet pigment from Chromobacterium violaceum UTM5 in textile dyeing. Biologia 71(2):121-127

Venil CK, Wahidin MAB, Aruldass CA, Ahmad WA (2017) Production of bacterial pigments in low cost medium and formulation of biodegradable ink. Indian J Exp Biol 55(7):441-447

Vila E, Hornero-Méndez D, Azziz G et al (2019) Carotenoids from heterotrophic bacteria isolated from Fildes Peninsula, King George Island, Antarctica. Biotechnol Rep 21:e00306

Villarreal P, Carrasco M, Barahona S et al (2016) Tolerance to ultraviolet radiation of psychrotolerant yeasts and analysis of their carotenoid, mycosporine, and ergosterol content. Curr Microbiol 72:94-101

Vincent WF, Downes MT, Castenholz RW, Howard-Williams C (1993) Community structure and pigment organisation of cyanobacteria-dominated microbial mats in Antarctica. Eur J Phycol 28(4):213-221

Visalakchi S, Muthumary J (2010) Antimicrobial activity of the new endophytic Monodictys castaneae SVJM139 pigment and its optimization. Afr J Microbiol Res 4:38-44

Voets IK (2017) From ice-binding proteins to bio-inspiredantifreeze materials. Soft Matter 13(28):4808-4823

Wackenroder H (1831) Ueber das Oleum radicis Dauci aetherum, das Carotin, den Carotenzucker und den officinellen succus Dauci; so wie auch über das Mannit, welches in dem Möhrensafte durch eine besondere Art der Gahrung gebildetwird. Geigers Magazin Pharmazie 33:144-172

Wada N, Sakamoto T, Matsugo S (2013) Multiple roles of photosynthetic and sunscreen pigments in cyanobacteria focusing on the oxidative stress. Metabolites 3(2):463-483

Walford J (ed) (1980) "Historical development of food colouration", in evelopments in Food Colours. Applied Science publishers, London

Wan A, Rozi AM, Bin MI et al (2014) A method for dyeing polyester fabrics using colorant extracted from Chromobacterium violaceum. MY150969 (A) (Patent).

Wang Y, Nakajima A, Hosokawa K et al (1020R) Cytotoxic prodigiosin family pigments from Pseudoalteromonas sp. 1020R isolated from the Pacific coast of Japan. Biosci Biotechnol Biochem 76:1229-1232. https://doi.org/10.1271/bbb.110984

Wehrs M, Gladden JM, Liu Y et al (2019) Sustainable bioproduction of the blue pigment indigoidine: expanding the range of heterologous products in R. toruloides to include non-ribosomal peptides. Green Chem 21(12):3394-3406

Wong LS, Teo SC (2014) Naturally occurring carotenoids in cyanobacteria as a bioindicator for heavy metals detection. In Proceedings of the international Conference on Advances. In: Applied Science and Environmental Engineering-ASEE.

World Health Organization (WHO) (2018) The top 10 causes of death. https://www.who.int/news-room/fact-sheets/detail/the-top10 -causes-of-death. Accessed 1 Jun 2018

Wynn-Williams DD, Edwards HGM (2002) Environmental UV radiation: biological strategies for protection and avoidance. In: Horneck G, Baumstark-Khan C (eds) Astrobiology. Springer, Heidelberg

Wynn-Williams DD, Edwards HGM, Garcia-Pichel F (1999) Functional biomolecules of Antarctic stromatolitic and endolithic cyanobacterial communities. Eur J Phycol 34(4):381-391

Yamashita M, Nakagawa Y, Li H, Matsuyama T (2001) Silica geldependent production of prodigiosin and serrawettins by Serratia marcescens in a liquid culture. Microbes Environ 16:250-254

Yarzábal LA (2016) Antarctic psychrophilic microorganisms and biotechnology: history, current trends, applications, and challenges. Microbial models: from environmental to industrial sustainability. Springer, Singapore, pp 83-118

Yoshida K, Hashimoto M, Hori R et al (2016) Bacterial long-chain polyunsaturated fatty acids: their biosynthetic genes, functions, and practical use. Mar Drugs 14(5):94

Yu D, Xu F, Valiente J et al (2013) An indigoidine biosynthetic gene cluster from Streptomyces chromofuscus ATCC 49982 contains an unusual IndB homologue. J Ind Microbiol Biot 40(1):159-168

Yumusak C, Prochazkova AJ, Apaydin DH et al (2019) Indigoidinebiosynthesized organic semiconductor. Dyes Pigm 171:107768

Yurkova AM, Vustin MM, Tyaglov BV et al (2008) Pigmented basidiomycetous yeasts are a promising source of carotenoids and ubiquinone Q10. Microbiology 77:1-6

Zerrad A, Anissi J, Ghanam J et al (2014) Antioxidant and antimicrobial activities of melanin produced by a Pseudomonas balearica strain. J Biotechnol Lett 5:87-94

Zhang X, Ma X, Wang N, Yao T (2008) New subgroup of Bacteroidetes and diverse microorganisms in Tibetan plateau glacial ice provide a biological record of environmental conditions. FEMS Microbiol Ecol 67:21-29. https://doi.org/10.111 1/j.1574-6941.2008.00604.x

Zobell C, Upham HC (1944) A list of marine bacteria including descriptions of new species. BidL. ScrippsIns£. Oceanogr 5:n9-292

Publisher's Note Springer Nature remains neutral with regard to jurisdictional claims in published maps and institutional affiliations. 